\title{
Paleogene evolution of the External Betic Zone and geodynamic implications
}

\author{
F. GUERRERA ${ }^{1} \quad$ M.A. MANCHEÑ $0^{2} \quad$ M. MARTíN-MARTíN ${ }^{3} \quad$ G. RAFFAELLI ${ }^{1} \quad$ T. RODRÍGUEZ-ESTRELLA ${ }^{4}$ F. SERRAN0 $0^{5}$
}

'Dipartimento di Scienze della Terra, della Vita e dell'Ambiente (DiSTeVA), Università degli Studi di Urbino "Carlo Bo" Campus Scientifico E. Mattei, 61029 Urbino, Italy. Guerrera E-mail: francesco.guerrera@uniurb.it Tel: (+39) 0722-304.224; Raffaelli E-mail: giuliana.raffaelli@uniurb.it

2Departamento de Química Agrícola, Geología y Edafología, Facultad de Química, Universidad de Murcia 30100 Murcia, Spain. E-mail: cheno@um.es

\author{
3Departamento de Ciencias de la Tierra y Medio Ambiente, Universidad de Alicante \\ Campus San Vicente, AP-99, 03080 Alicante, Spain. E-mail: manuel.martin.m3@gmail.com
}

${ }^{4}$ Departamento de Ingeniería Minera, Geologíca y Cartográfica, Universidad

Politécnica de Cartagena

30202 Cartagena Spain. E-mail: tomasrestrella@hotmail.com

${ }^{5}$ Departamento de Ecología y Geología, Universidad de Málaga

Campus de Teatinos, 29071 Malaga, Spain. E-mail: F.Serrano@uma.es

\begin{abstract}
A B S T R A C T
Interdisciplinary studies combining field data (geological and tectonic mapping, lithostratigraphic reconstructions, lithofacies characterization, correlations and sampling) and laboratory analyses (biostratigraphy, chronostratigraphy, clay mineralogy and sandstone petrography) of eight Senonian-Paleogene successions from the Sierra de La Pila and Sierra de El Carche areas (Murcia province, SE Spain) belonging to the External Betic Zone are presented. Field evidence of tectonic activity (slumps, olistostromes, syn-genetic folds, lateral variability, changes in thicknesses, para- and unconformity boundaries, stratigraphic gaps, shallowing upward trends to emersion, etc.) was found in several Paleogene intervals. The results enable a better reconstruction of the stratigraphic architecture and chronostratigraphy of the Paleogene record, highlighting in particular: facies evolution, discontinuities, depositional sequences (Middle-Upper Maastrichtian, Upper Paleocene-Middle Eocene, Oligocene-Lower Aquitanian), environmental evolution (homogeneous conditions during the Late Cretaceous and successive realm diversification from platform to slope to basin) and correlations, along the Prebetic to Subbetic transition, which is a key sector to understand the northeastward variations of the South Iberian margin. A conclusive paleogeographic and geodynamic evolutionary model for the study area is proposed, hypothesizing that Paleogene compressive tectonics affected the eastern External Betic Zone. In addition, correlations with successions from the western External Betic Zone evidenced asynchronous deformation from east to west along the internalmost External Betic Zone. Moreover, a comparison with the external Tunisian Tell enables the recognition of similar sedimentarytectonic events, imposing new constraints in the Paleogene geodynamic reconstruction throughout the western Tethys.
\end{abstract}




\section{GEOLOGICAL SETTING AND AIM}

The Betic Cordillera (Fig. 1) is classically divided into Internal and External Betic Zones and the Campo de Gibraltar Complex represents the interposed Maghrebian Flysch Basin Zone (Martín-Algarra, 1987; Guerrera et al., 2005, 2011; Alcalá et al., 2013; among others).

The Internal Betic Zone is composed mainly of three complexes of nappes (from bottom to top: Nevado-Filabride, Alpujarride and Malaguide), that underwent different alpine and neo-alpine deformative phases with associated metamorphic processes (mainly in the Nevado-Filabride and Alpujarride complexes) during the Cretaceous to Early Miocene. These internal nappes have a Paleozoic metamorphic basement and Triassic to Lower Miocene metamorphic and/or sedimentary alpine cover. This Internal Betic Zone reached its definitive structure in piles of nappes during the Early Burdigalian when it collided with the External Betic Zone (Martín-Algarra, 1987), forming the Internal-External Zone boundary.

The External Betic Zone is classically divided into two main tectono-paleogeographic domains derived from the South Iberian margin: i) the Prebetic domain, stratigraphically continuous with the northern foreland (Iberian Meseta), that in turn is divided, from SE to NW, into Internal and External
Prebetic sub-domains; ii) the unrooted Subbetic domain (southward from the Prebetic), divided, from south to north, into the Internal, Median, and External Subbetic sub-domains. Both the Prebetic and Subbetic domains are represented by Triassic to Tertiary sedimentary successions progressively structured, from south to north, as a pile of nappes during the Middle-Late Miocene, after the formation of the InternalExternal Zone boundary (Vera, 2000; Arias et al., 2004; and references therein), which is indicated in Figure 1.

The general Betic framework is completed with the Maghrebian Flysch Basin units, outcropping mainly in the western Betics (Campo de Gibraltar) and sandwiched as tectonic slices along the contact between Internal-External Zone boundary mainly in the central and eastern Betic Cordillera. The units derived from this Maghrebian Basin are composed of Cretaceous to Lower Miocene deep sedimentary marine successions (probably deposited on an oceanic and/ or thinned crust) which, in the upper portion, are made up of thick flysch deposits. These units show a strong tectonic deformation and are structured in thrust sheets starting from the Early Burdigalian (Martín-Algarra, 1987; Guerrera et al., 1993; Guerrera et al., 2005, 2011; Alcalá et al., 2013). Neogene basins and Middle-Late Miocene volcanic rocks showing a post-orogenic character (Arias et al., 2004), complete the geological framework of the Betic chain Cordillera.

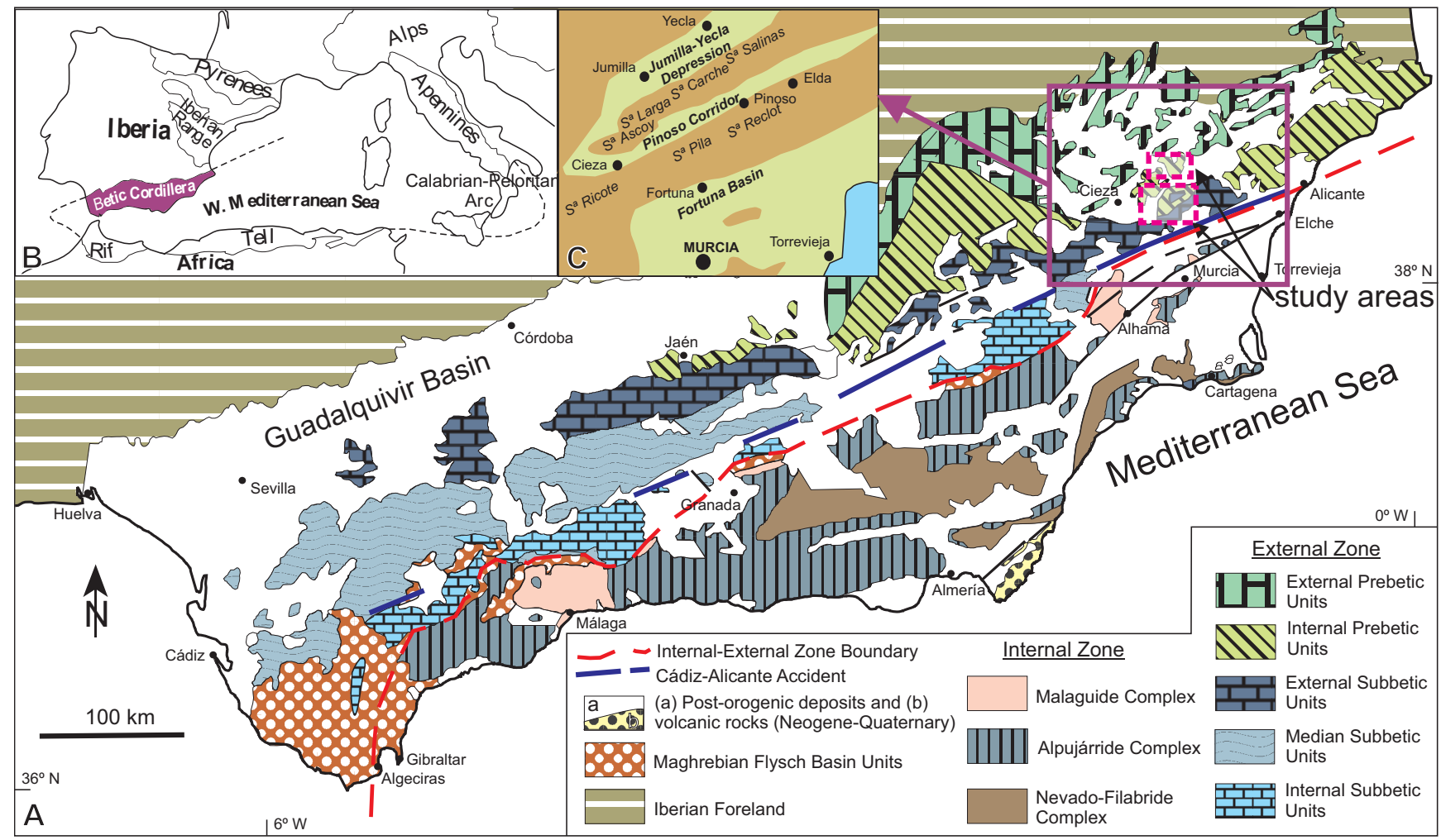

FIGURE 1. A) Geological map of the Betic Cordillera with the location of the study areas (pinkish boxes); B) Position of the Betic Cordillera in the framework of the western Mediterranean Alpine belts; C) Geographic sketch of the study area with indication of the main locality and geologic structures (basin, corridor and depression). 
In the Murcia and Alicante provinces, the External Betic Zone today appears incomplete, only the Prebetic and the externalmost Subbetic sub-domains crop out in contact with the Internal Betic Zone (see Fig 1). Moreover, in the Alicante sector, gentle Early Paleogene tectonic activity affecting the eastern External Betics and linked to the Nevado-Filabride Alpine deformation was proposed by Guerrera et al. (2006). The latter region seems to have been a crucial paleogeographic area because it represents the northeastward transition to the Iberian Range but in a close position to the Internal Betic Zone (located eastward). This area could undergo a Paleogene (Pyrenean-like) deformation also affecting the sedimentation in the southeastern Iberian margin.

The present study shows the reconstruction of the Senonian-Paleogene stratigraphic record based on the study of eight stratigraphic sections, six located in the Sierra de La Pila sector and two in the Sierra de El
Carche sector of the Murcia province (Figs. 1; 2). Field data (geological and tectonic mapping, lithostratigraphy, lithofacies association, sample collection, etc.) has been integrated with laboratory analyses (biostratigraphy, chronostratigraphy, clay mineralogy and sandstone petrography). The study, with accurate biostratigraphic control, has enabled the identification of unconformities, depositional sequences, stratigraphic gaps and sedimentary trends, which have been integrated in a model of tectonic-sedimentary evolution.. In the Betics, it is accepted that the inversion of the tectonic regime (from distension to compression) occurred in the latest Cretaceous (Martín-Algarra, 1987), while the nappe tectonics started in the Early Miocene in the External Betic Zone (Arias et al., 2004). Our paper highlights the effects of the deep tectonics during the sedimentation (blind thrust and deep growing fold) in the period from the beginning of the tectonic inversion to the activation of the nappe tectonics.
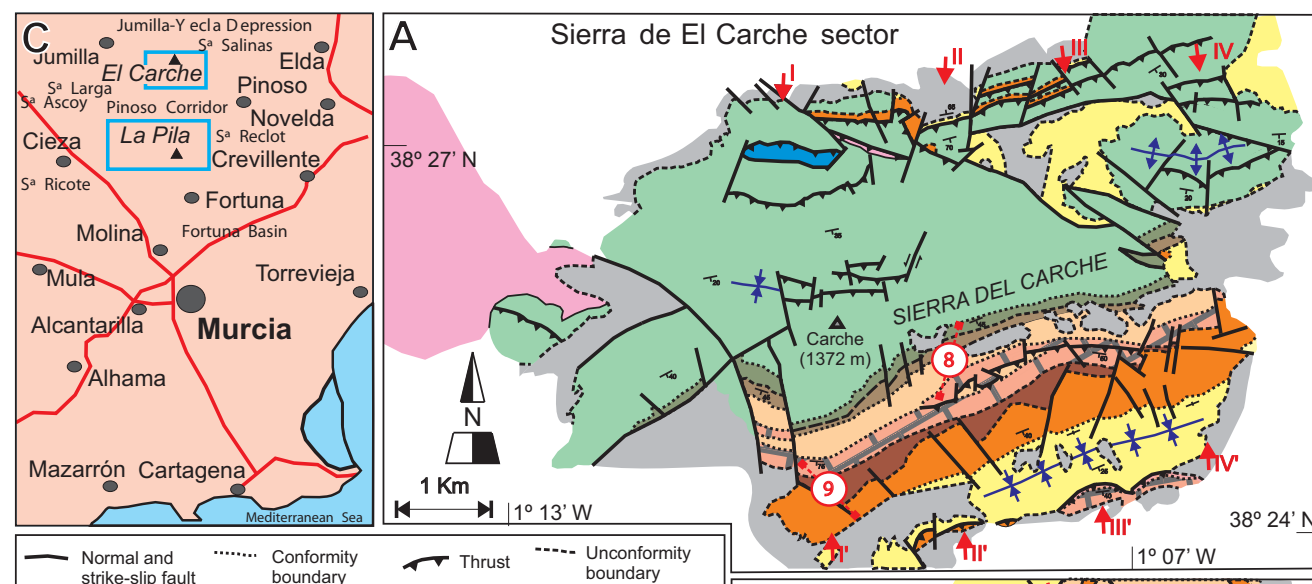
Cycle VIII (Vera, 2000) Conglomerates, silts and clays (Pliocene-Quaternary) Cycle VII (Vera, 2000) Tap Fm.:marls and diatomites with sandstones and calcarenites (Lower Langhian-Tortonian) $\square$ Congost Fm.:conglomerates, calcarenites and algal limestones (Lower Langhian) Cycle VI (Vera, 2000)

Murtas Fm.:conglomerates, clays, limestones and black levels (Oligocene-Upper Aquitanian)

Miñano Fm.:ma

Mith larger...massive limestones with larger foraminifera and slumps at the bottom (Middle-Upper Eocene) Paleocene-Upper Lutetian)

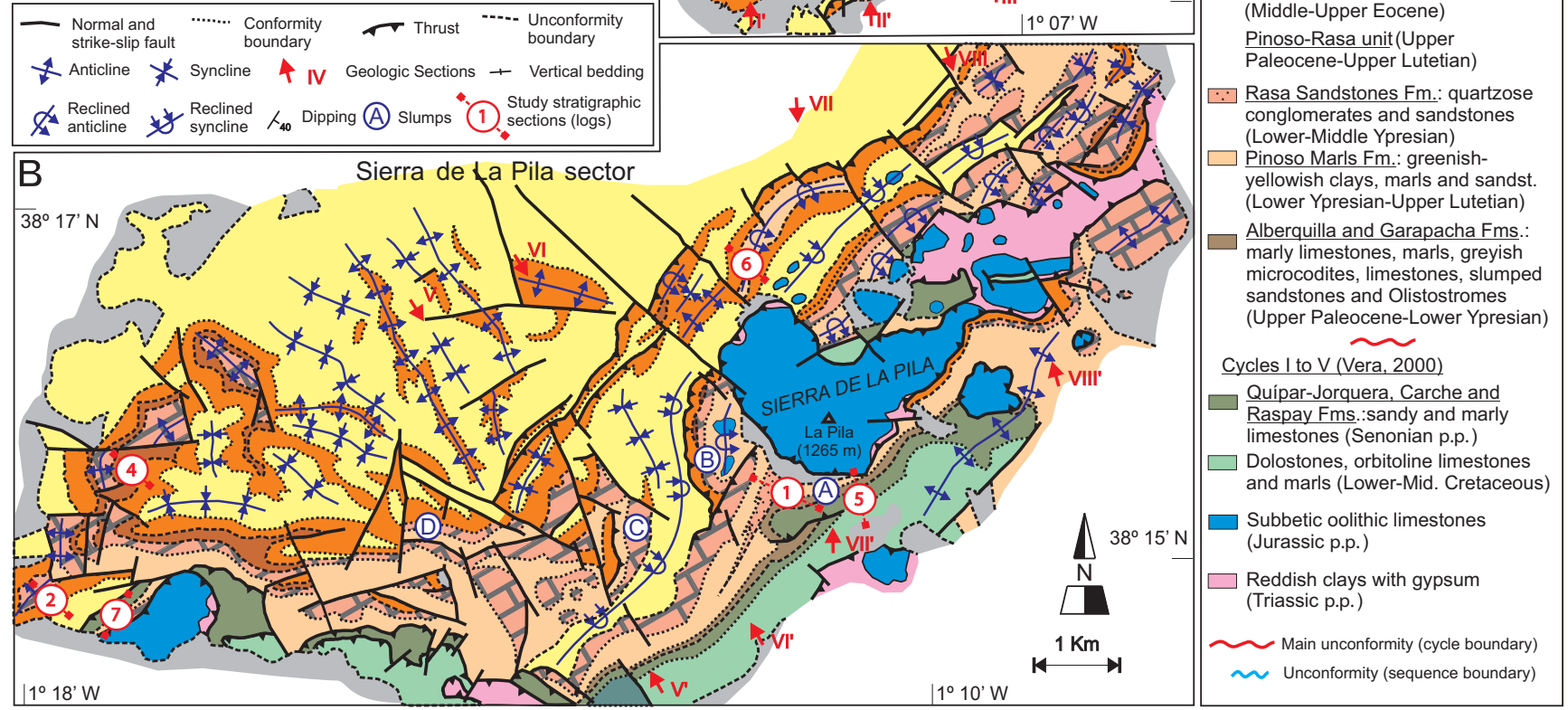

FIGURE 2. Detailed geological maps of the sectors studied: A) Sierra de El Carche; B) Sierra de La Pila. C) Geographic sketch of the Murcia province with indication of the studied areas. In A and B boxes the location of measured logs and the orientation of the geological sections represented in Figure 3 are also shown. 
The interdisciplinary data from this study have been integrated with data on the Oligocene-Miocene sedimentation of similar successions from the Alicante region (Guerrera et al., 2006), allowing a better definition of the Paleogene tectonic phases.

Finally, an evolutionary paleogeographic-geodynamic model is proposed for the study area. In addition, some correlations with similar external sectors of the Betic Cordillera and Tunisian Tell (Maghrebian Chain), previously analyzed by several authors, allow certain deductions with implications for the evolution of the western Tethys area.

\section{PREVIOUS STUDIES}

The study area is located to the north of Murcia province (SE Spain), in the Sierra de La Pila and Sierra de El Carche sectors (Fig. 2). The geological studies in the area started at the end of the nineteenth century (e.g. Nicklés, 1896a,b) and continued throughout the twentieth century to the present.

The study area represents the Prebetic-Subbetic domain transition of the South Iberian margin (eastern External Betic Zone), as indicated by Azéma (1966a, 1966b, 1977). Two mountain alignments coinciding with north-verging foldthrusting nappes can be recognized (Rodríguez-Estrella, 1977, 1979): the Sierra de Ricote-Sierra de La Pila-Sierra de El Reclot, to the south, and the Sierra de Ascoy-Sierra Larga-Sierra de El Carche-Sierra de Salinas, to the north. These alignments are bounded by the Fortuna Basin to the south, the Pinoso Corridor in the middle, and the Jumilla-Yecla depression to the north. The area is affected by several recent and active faults (Foucault, 1960; Montenat, 1977; Sanz de Galdeano, 1983; Alfaro-García, 1995) and diapirs (Seyfried, 1978; De Smet, 1984a, 1984b; Martínez del Olmo et al., 1986).

According to the literature (Azema, 1977; RodríguezEstrella, 1977, 1979), in the area during the Mesozoic (Jurassic predominantly), the Prebetic domain (externalmost position) evolved as a distal shallow carbonate platform, while the Subbetic domain (internalmost position) underwent subsidence, allowing deposition of marly pelagic to deep-water sediments. During the Cretaceous a deep pelagic facies (Scaglia-like) homogenization occurred. During the Tertiary this changed to detritic sedimentation, where marly or calcareous intervals alternated with a terrigenous supply (Azema, 1977; Vera, 2000; Chacón and Martín-Chirivel, 2005). The deformational evolution during the Neogene is thought to have had several phases (Montenat, 1977): thrusting during the Late Burdigalian, normal faulting during the Middle Miocene, and strike-slip faulting and folding during the Late Miocene.

In conclusion, the extensive information from the numerous previous studies is important to explain the different geological aspects of the region. The contradictory findings reported in the literature will be discussed below, taking into account our new data. In particular, for the sedimentary record studied (mainly Paleogene), several names of formations and ages were assigned in literature. The correlation between the different formations from the more recent literature and the ones used in the present paper is synthesized in Table 1.

The geological and structural framework of the study area (Table 1) is synthesized in the geological map in Figure 2, distinguishing the sector of Sierra de El Carche and Sierra de La Pila, where detailed tectonic elements have been reported. In this figure, the stratigraphy is of Vera (2000) updated with ournew data. To complete the structural context, eight geological sections were performed in the Sierra de El Carche and Sierra de La Pila sectors taking into account the eight main cycles considered by Vera (2000) in the area (Fig. 3).

\section{RESULTS}

\section{Field data and lithostratigraphy}

The Upper Cretaceous-Paleogene stratigraphic record was studied in the Sierra de La Pila and Sierra de El Carche areas (Province of Murcia) by means of eight stratigraphic sections (Figs. 2; 3; 4; Table 2) located in the External Betic Zone, along the Prebetic/ Subbetic domains transition. Logs 1, 2, 4, 5, 6, and, 7 were measured in Sierra de La Pila and $\operatorname{logs} 8$ and 9 in Sierra de El Carche.

The total stratigraphic record studied is more than $2200 \mathrm{~m}$ in thickness, where 102 samples were collected for biostratigraphic, mineralogic and petrographic analyses. The main field data (log number, locality, UTM coordinates, informal units established in the field, thickness, samples, main lithofacies and character of the boundaries) are listed in Table 2 .

On the basis of the correlation between the defined field units and the formations from literature (Table 1), we summarize the main stratigraphic record studied in the Prebetic-Subbetic transition along the Eastern Betic Zone below.

The lowermost El Carche Fm. (Chacón and MartínChirivet, 2005), cropping out in the Sierra de El Carche sector, corresponds to the Quípar-Jorquera Fm. (Hoedemaeker, 1973; Vera, 2000), in the Sierra de La Pila sector. Only the upper part (A) of the two formations was studied. The main lithofacies consist of fossiliferous (Inoceramus) limestones, marly limestones, and sandy marls in thin beds, being more 
TABLE 1. Correlated formations of the Senonian-Paleogene formations studied in the Prebetic-Subbetic transition of the eastern External Betic Zone

\begin{tabular}{|c|c|c|c|c|c|c|c|c|}
\hline \multirow{3}{*}{$\begin{array}{c}\text { Age of literature } \\
\text { (Durand-Delga and Magné, 1958; } \\
\text { Hoedemaeker, 1973; Ferriz et al., 1993; } \\
\text { Vera, 2000; Chacón and } \\
\text { Martín-Chirivet, 2005) }\end{array}$} & \multicolumn{4}{|c|}{ Previous stratigraphy } & \multicolumn{4}{|c|}{ This paper } \\
\hline & \multirow[b]{2}{*}{ Van Ven (1969) } & \multirow[b]{2}{*}{ Hoedemaeker (1973) } & \multirow[b]{2}{*}{ Vera $(2000)$} & \multirow{2}{*}{$\begin{array}{c}\text { Chacón } \\
\text { and } \\
\text { Martín-Chirivet } \\
(2005) \\
\end{array}$} & \multicolumn{2}{|c|}{ Sierra de El Carche $\square$ sector } & \multicolumn{2}{|c|}{ Sierra de La Pila $\square$ sector } \\
\hline & & & & & Unit & $\begin{array}{c}\text { Field } \\
\text { Unit } \\
\text { (logs) }\end{array}$ & Unit & $\begin{array}{l}\text { Field Unit } \\
\text { (logs) }\end{array}$ \\
\hline $\begin{array}{c}\text { Oligocene- } \\
\text { Lower Aquitanian }\end{array}$ & \multirow{6}{*}{$\begin{array}{l}\text { Gredero } \\
\text { Fm. }\end{array}$} & Murtas Fm. & \multirow{5}{*}{ Grupo Cardela } & \multirow{5}{*}{$\begin{array}{l}\text { Not } \\
\text { studied }\end{array}$} & Murtas Fm. & G & Murtas Fm. & G \\
\hline \multirow{4}{*}{ Eocene } & & $\begin{array}{l}\text { Almanillas } \\
\text { Fm. }\end{array}$ & & & & & & \\
\hline & & $\begin{array}{l}\text { Somogil } \\
\text { Marls Fm. }\end{array}$ & & & $\begin{array}{c}\text { Miñano Limestones } \\
\text { Fm. }\end{array}$ & $\mathrm{F}, \mathrm{J}$ & $\begin{array}{l}\text { Miñano } \\
\text { Limestones }\end{array}$ & $\mathrm{F}$ \\
\hline & & $\begin{array}{l}\text { Miñano Limestones } \\
\text { Fm. }\end{array}$ & & & & & & \\
\hline & & \multirow[t]{2}{*}{$\begin{array}{c}\text { Rasa Sandstones } \\
\text { Fm. }\end{array}$} & & & \multirow[t]{2}{*}{$\begin{array}{l}\text { Pinoso-Rasa unit } \\
\text { (Pinoso Marls Fm.) }\end{array}$} & \multirow[t]{2}{*}{ E1 } & Pinoso-Rasa Unit & E2 \\
\hline & & & & $\begin{array}{l}\text { Pinoso } \\
\text { Fm }\end{array}$ & & & \multirow{3}{*}{$\begin{array}{l}\text { Garapacha } \\
\text { Unit }\end{array}$} & \multirow{3}{*}{$\mathrm{C}, \mathrm{D}, \mathrm{N}, \mathrm{M}$} \\
\hline \multirow{2}{*}{ Paleocene } & \multirow{3}{*}{$\begin{array}{l}\text { Jorquera } \\
\text { Fm. }\end{array}$} & $\begin{array}{l}\text { Moro Marls } \\
\text { Fm. }\end{array}$ & \multirow{4}{*}{\begin{tabular}{c|} 
Quípar- \\
Jorquera Fm.
\end{tabular}} & \multirow{2}{*}{ Alberquilla Fm. } & \multirow{2}{*}{$\begin{array}{l}\text { Alberquilla } \\
\text { Fm. }\end{array}$} & \multirow{2}{*}{$\mathrm{C}, \mathrm{K}$} & & \\
\hline & & \multirow{3}{*}{$\begin{array}{c}\text { Quípar-Jorquera } \\
\text { Fm. }\end{array}$} & & & & & & \\
\hline \multirow{2}{*}{ Senonian } & & & & $\begin{array}{l}\text { Raspay } \\
\mathrm{Fm} .\end{array}$ & Raspay Fm. & B & Raspay Fm. & B \\
\hline & $\begin{array}{l}\text { Quípar } \\
\text { Fm. }\end{array}$ & & & $\begin{array}{l}\text { Carche } \\
\text { Fm. }\end{array}$ & $\begin{array}{l}\text { Carche } \\
\text { Fm. }\end{array}$ & A & \begin{tabular}{|c|}
$\begin{array}{c}\text { Quípar-Jorquera } \\
\text { Fm. }\end{array}$ \\
\end{tabular} & A \\
\hline
\end{tabular}

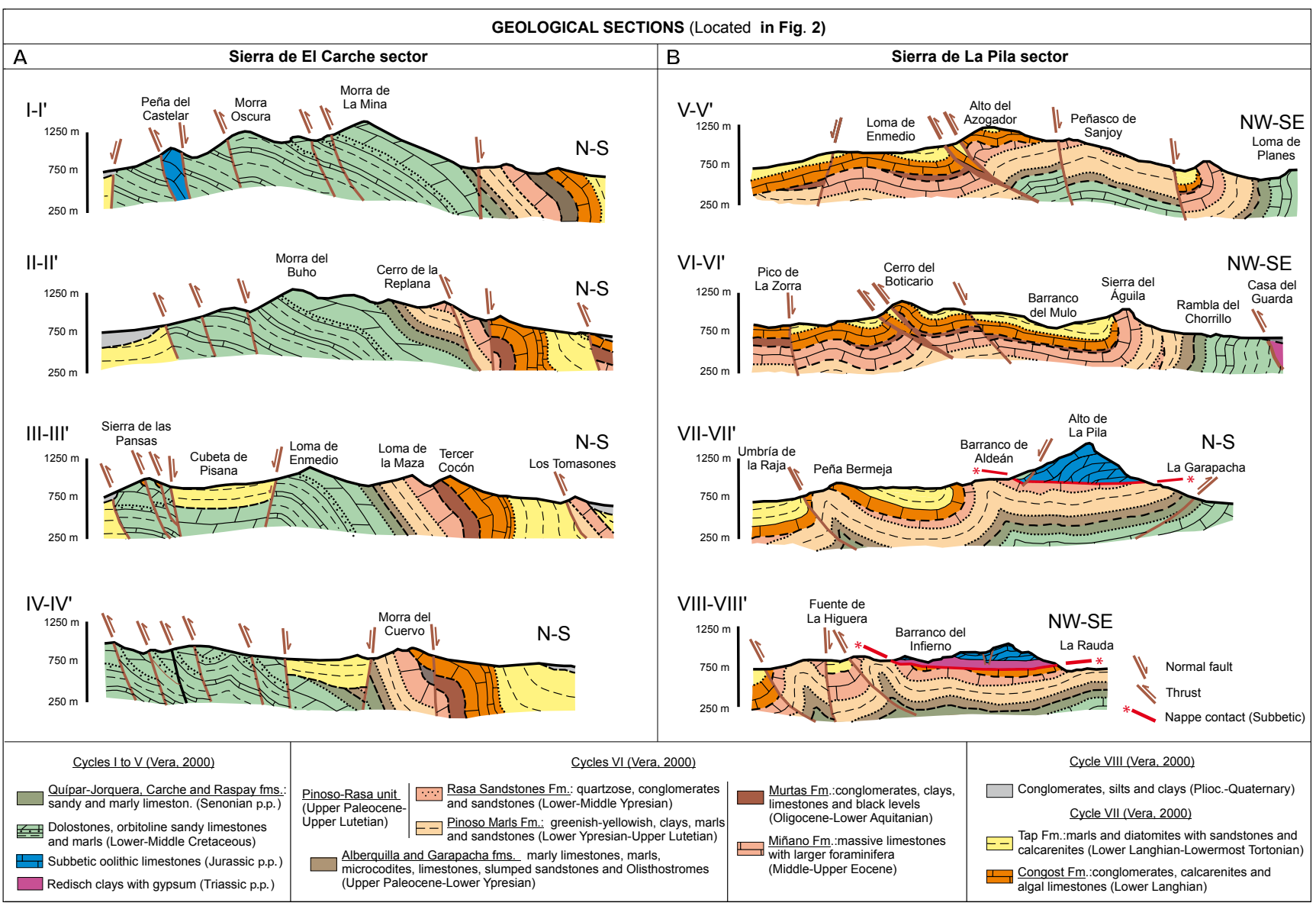

FIGURE 3. Eight geological sections synthesize the structural framework of the study area taking into account the eight main tecto-sedimentary cycles considered by Vera (2000): A) Sierra de El Carche sector; B) Sierra de La Pila sector. The locations and orientations of the sections are indicated in Figure 2. 
TABLE 2. Major field data from Sierra de El Carche (more proximal) and Sierra de La Pila (more distal) sectors including: log numbers, localities, UTM coordinates, field, thicknesses, samples, main lithofacies and characters of the boundaries

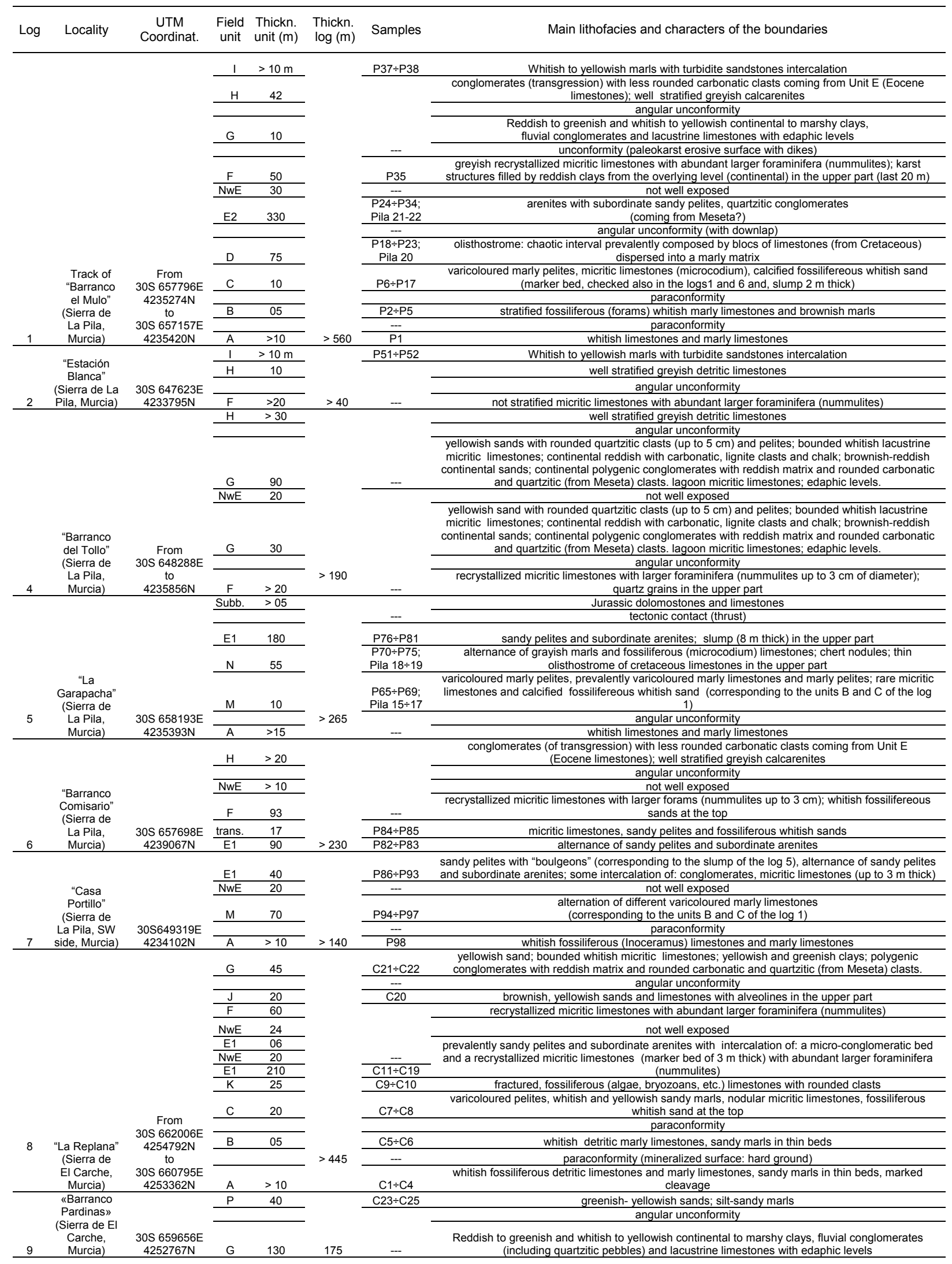




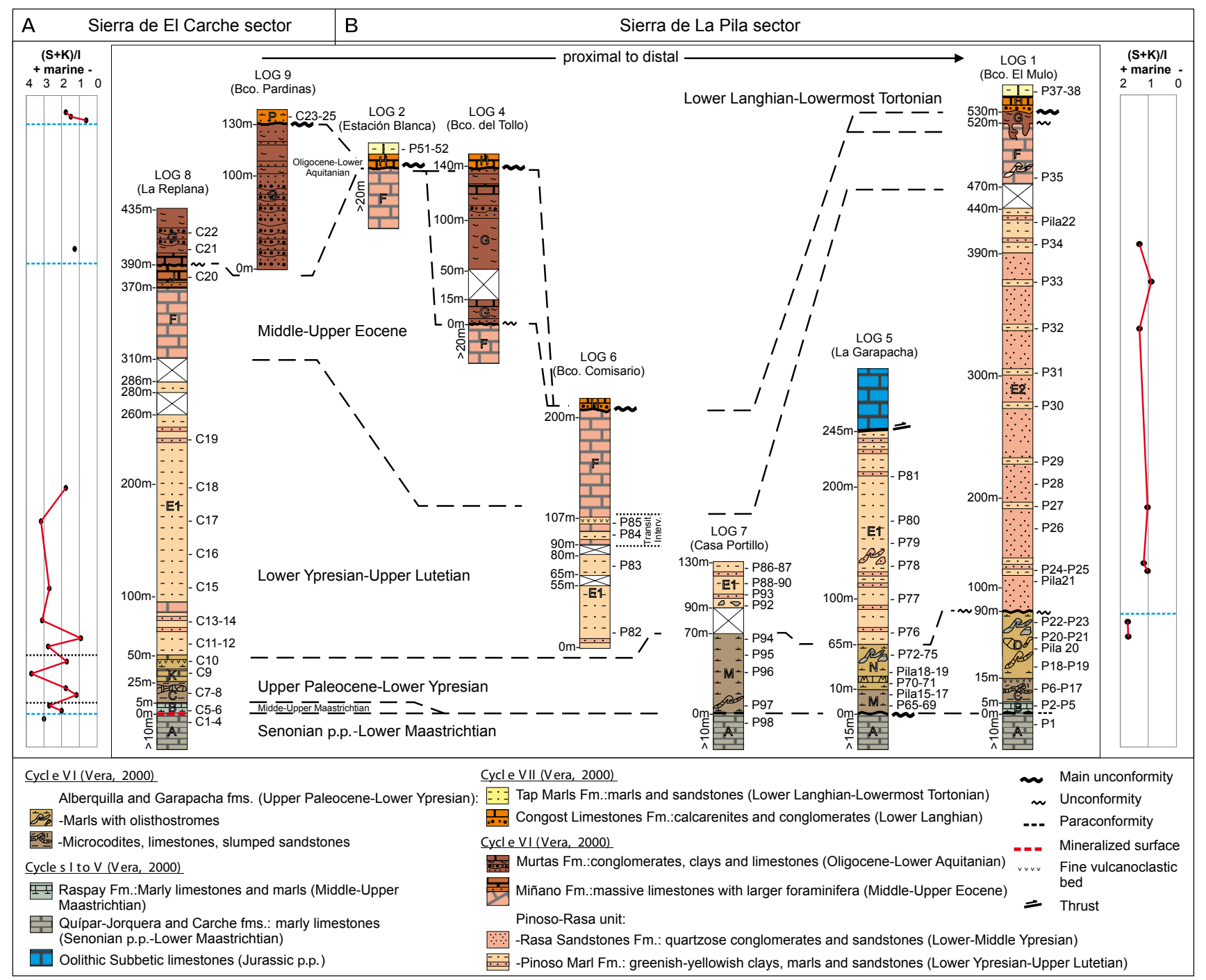

FIGURE 4. Lithostratigraphy of the eight measured logs (located in Figure 2) and correlation with the curves resulting from the [(S+K)/I] ratio: A) Sierra de El Carche sector; B) Sierra de La Pila sector. The stratigraphic units are grouped according to the cycles of Vera (2000).

detritic in the Sierra de El Carche sector. A transition from neritic to pelagic environment can be interpreted from Sierra de El Carche to Sierra de la Pila sector.

Unit B of both sectors corresponds to the Raspay Fm. (Chacón and Martín-Chivelet, 2005) and consists of thinly bedded sandy marls and marly limestones, interpreted as a pelagic environment. A minor paraconformity has been registered between the Raspay Fm. and the underlying succession.

Units C and $\mathrm{K}$ belong to the Alberquilla Fm. (Chacón and Martín-Chivelet, 2005) defined in the Sierra de El Carche sector. This formation can be correlated with the Garapacha stratigraphic unit (proposed here for the first time), which includes units $\mathrm{C}, \mathrm{D}, \mathrm{N}$, and $\mathrm{M}$ in the Sierra de La Pila sector. The lithofacies association exposed in Table 2 indicates a carbonate platform in the El Carche sector with algae, bryozoans, nodular micritic limestone, and rounded clasts. In the Sierra de la Pila sector this carbonate platform (ramp-like) grades eastwards into slope environments, where numerous slumps and olistostromes have been found. An unconformity has been registered between the former and the underlying succession (Fig. 4).

The following Pinoso-Rasa stratigraphic unit, corresponding to different formations in the literature (Table 1) is defined here for the first time (unit E) including the Pinoso marls Fm. (E1) and Rasa sandstones Fm. (E2) both from literature. These formations can be differentiated with the arenitic/pelitic $(\mathrm{a} / \mathrm{p})$ ratio, a common criterion to distinguish turbiditic successions. The Pinoso marl Fm. is a pelitic unit $(\mathrm{a} / \mathrm{p}<30 \% / 70 \%)$ recognized in most of the logs 
studied, while the Rasa sandstones Fm. is an arenitic unit (a/p $>70 \% / 30 \%$ ) exposed only in the Barranco del Mulo (Log 1, Sierra de La Pila sector) indicating an area favorable for terrigenous supply. An unconformity is registered in the log 1 (Barranco del Mulo) separating the Rasa sandstones Fm. from the Garapacha stratigraphic unit. and a lateral change of facies between the Rasa sandstones and Pinoso marls fms. is also observed. The Pinoso-Rasa stratigraphic unit shows some features (turbidites, slumps, etc.) that can be related to a slope environment represented in both constituent formations.

The Miñano Limestones Fm. (Hoedemaeker, 1973), corresponding to different formations in the literature (Table 1) and coinciding with units $\mathrm{F}$ and $\mathrm{J}$ in both sectors, may represent internal platform conditions, as suggested by the presence of larger foraminifera (nummulites and alveolines). Alveolines are more abundant in the Sierra de El Carche sector, while nummulites are widespread in both sectors. A gradual passage is observed between PinosoRasa stratigraphic unit and Miñano limestones Fm. in the $\log 6$ (Barranco Comisario). A level with slumps and intraformational folds is recognized in the Barranco del Mulo area, indicating tectonic instability in the platform.

The top of the sequence corresponds to the Murtas Fm. of Hoedemaeker (1973). In both sectors, it is equivalent to unit $\mathrm{G}$, which may represent a transition from a marshy/ beach/lagoon yellow marls and sands to fluvial (continental red beds with conglomerates, sands, silts, and clays) and lacustrine (white gastropod limestones) environments. This formation is clearly unconformable over the underlying formations, making a discontinuity with a paleokarst surface well recognized in several outcrops.

The study successions ( $\operatorname{logs} 1,2,4,6$ and 9) ended with the beginning of the overlying Miocene formations: i) the Congost limestones Fm., consisting of red to white shallow marine limestones and calcarenites (unit $\mathrm{H}$ ) and ii) the Tap marls Fm. consisting of white to yellow marine marls with intercalation of turbiditic sandstones (unit I). An unconformity is registered separating the base of this new sedimentary cycle from the underlying formations.

The vertical and lateral distribution of the lithofacies associations recognized in the study area indicate a marked diversification in the paleoenvironments from proximal (Sierra de El Carche) to distal (Sierra de La Pila) areas from the source area (Iberian Meseta), where tilted, lowered, uplifted, and sometimes emerged blocks are present.

\section{Biostratigraphy and Chronostratigraphy}

A biostratigraphic study of the Sierra de La Pila and Sierra de El Carche sectors based on the planktonic foraminifera assemblages (Table 3) was carried out in order to determine the chronostratigraphic and tectonosedimentary relationships in the study area (Fig. 5). The taxonomy and the biostratigraphic zonation used here were those established by Olsson et al. (1999) for the Paleocene planktonic foraminifera and by Pearson et al. (2006) for the Eocene planktonic foraminifera (Table 3).

The upper levels of the unit A (El Carche and Quipar-Jorquera fms.) show assemblages of Senonian globotruncanids not younger than Campanian or Early Maastrichtian. In the Sierra de La Pila sector ( $\log 7$ of Casa Portillo) the assemblages contain G. elevata, restricting the age of these levels to the Campanian, whereas in Sierra de El Carche sector ( $\log 8)$ the presence of G. subspinosa suggests that this unit could reach the Early Maastrichtian. These data agree with those reported in Chacón et al. (2004) and Chacón and Martín-Chivelet (2005), who assigned to El Carche Fm. an earliest Campanian-Early Maastrichtian age.

Unit B (Raspay Fm., Sierra de El Carche sector) contains assemblages characterized by the presence of $R$. contusa, pointing to the Middle-Late Maastrichtian. Chacón and Martín-Chivelet (2005) noticed the existence of a regional discontinuity between El Carche and Raspay fms. This discontinuity affects part of the Maastrichtian with variable grade depending on the sectors. Thus, the presence of G. calcarata in unit A in the Sierra de La Pila sector $(\log 1)$ indicates that the top of the Quipar-Jorquera fms. occurs before the end of the Campanian. This occurrence evidences a more important gap in the Sierra de La Pila sector (Late Campanian-Early Maastrichtian) than in the Sierra de El Carche sector (Early Maastrichtian).

It is noteworthy that the microfauna assemblages from units A and B in the Sierra de La Pila sector are made up almost entirely of planktonic foraminifera in a pelagic Scaglia-like facies. On the other hand, the sediments from the Sierra de El Carche sector contain more neritic biotic assemblages in which benthic foraminifers and echinoderm fragments predominate.

Unit C (Alberquilla Fm. and Garapacha stratigraphic unit) can also be Late Maastrichtian (Senonian) in age at the base because the planktonic foraminifera assemblages contain $R$. contusa and A. mayaroensis. Therefore, the discontinuity between the Raspay Fm. and its overlying Alberquilla Fm. (in Sierra de El Carche sector) and Garapacha stratigraphic unit (in Sierra de La Pila sector) seems to affect also the Maastrichtian. This statement disagrees with Rodríguez-Estrella (1977) and Chacón and Martin-Chivelet (2005), who considered all the sediments above the Raspay Fm. belonging to the Paleogene.

We detected the Cretaceous-Paleogene transition in the unit $\mathrm{K}$ (upper part of the Alberquilla Fm.) and in the equivalent unit $\mathrm{D}$ of the $\log 1$ (upper Garapacha 
TABLE 3. Most significant species comprising the planktonic foraminifera assemblages from different lithostratigraphic units of the Paleogene succession studied in the Sierra de El Carche and Sierra de La Pila sectors._The biostratigraphic characterization is based on the zonal scales from Olsson et al. (1999) and Pearson et al. (2006); while the correlation between biostratigraphy and chronology is from Luterbacher et al. (2004)

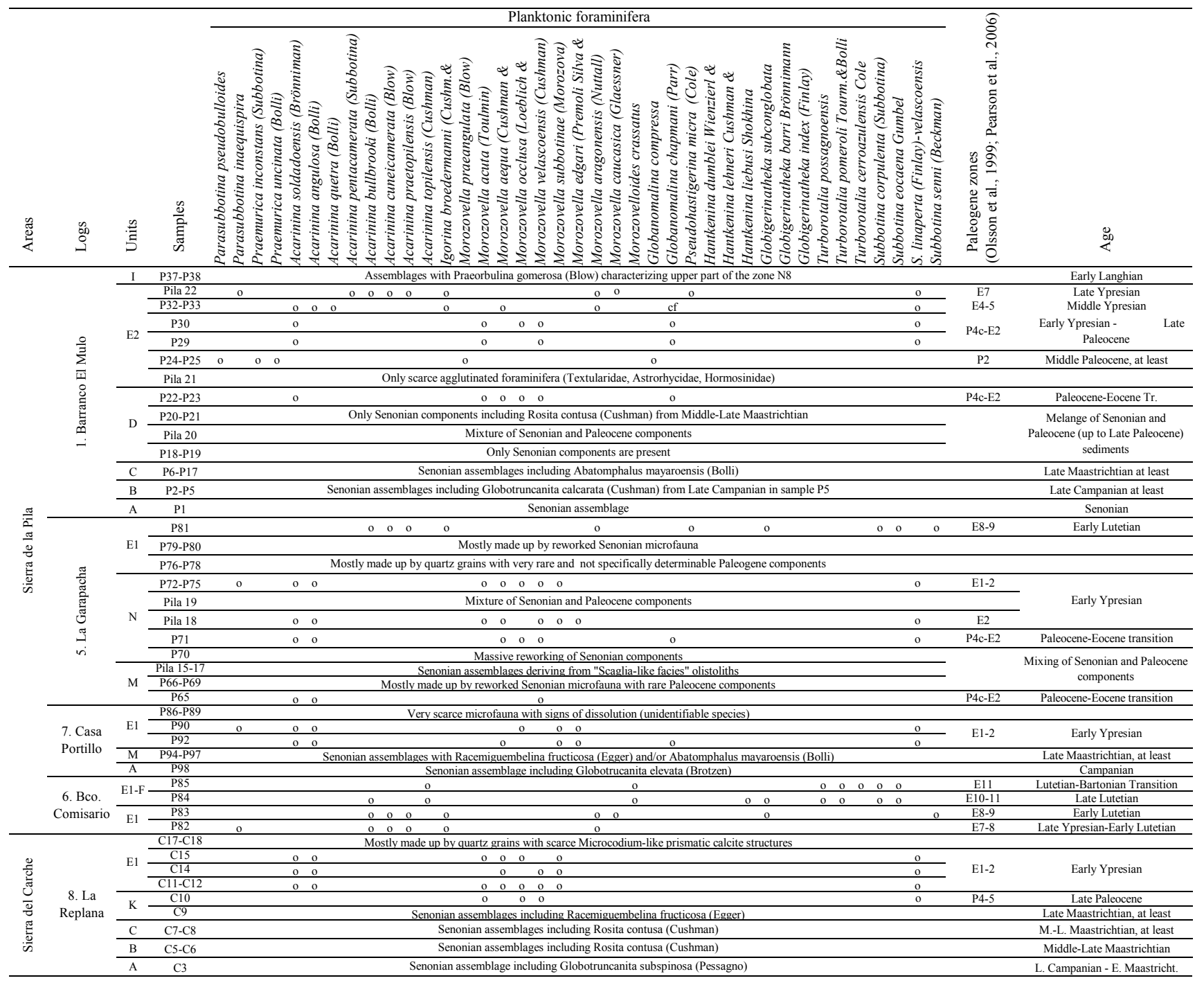

stratigraphic unit p.p.) but with different characteristics. In the Sierra de El Carche sector, the lower level (sample C9) of unit $\mathrm{K}$ still shows assemblages of Late Maastrichtian age with $R$. fructicosa, whereas upwards the level $\mathrm{C} 10$ yields an assemblage with $M$. acuta, $M$. occlusa, and $M$. velascoensis, specifying the zonal interval P4-P5 of the Late Paleocene. Consequently, a discontinuity affecting the end of the Cretaceous and the Early-Middle Paleocene is detected within unit K. On the other hand, in the Sierra de La Pila sector $(\log 1)$, unit D is composed of a mélange of Senonian and Paleogene sediments. The younger planktonic foraminifera, e.g. M. angulata, indicate that deposits from the Late Paleocene, at least, are involved in the mélange. In addition, the uppermost levels of unit D in this sector (samples P22 and P23) contain assemblages with $M$. velascoensis, M. aequa, and $M$. soldadoensis, indicating the biostratigraphic interval P4c-E2 of the Paleocene-Eocene transition. In the La Garapacha stratigraphic section ( $\log 5)$ located towards a more proximal area, units $\mathrm{M}$ and $\mathrm{N}$ (also Raspay-Alberquilla Fm. and Garapacha stratigraphic unit) also show a mélange of Cretaceous and Paleogene sediments. Frequently, this mélange consists of masses of Senonian Scaglia-like sediments, intercalated as olistoliths between levels containing only Paleogene microfauna in apparently consistent assemblages. In these cases, a certain chronostratigraphic control is possible. Thus, the lower bed sampled from unit M (sample P65) and the level P71 from the unit $\mathrm{N}$ contain assemblages with A. soldadoensis, A. angulosa, and M. velascoensis, marking an age close to the Paleocene-Eocene boundary (zonal interval P4c-E2). Levels of the middle part (sample Pila18) and upper part (samples P72-P75) of 
unit $\mathrm{N}$ show assemblages of the Early Ypresian (zone E1-2), in which $M$. subbotinae appears in combination with the above-mentioned species.

Given that units $\mathrm{C}, \mathrm{M}, \mathrm{K}, \mathrm{N}$, and $\mathrm{D}$ are lateral equivalents and belong to the Alberquilla Fm. and Garapacha stratigraphic unit, the whole ensemble should be considered as Late Paleocene to Early Ypresian in age and related to an olistostrome deposition made of reworked Senonian material. This implies that a gap affects the Early Paleocene, which can reach the Late Paleocene (up to Zone P4 p.p.) towards the proximal sectors.

The input of sediments comprising unit E (Pinoso-Rasa stratigraphic unit) occurs at different ages, depending on the sector considered. In the more proximal areas (Sierra de El Carche sector) the lower levels (C11-C12) of unit E contain A. soldadoensis, A. angulosa, M. velascoensis, M. occlusa, $M$. acuta, M. aequa and M. subbotinae. This assemblage suggests deposition during the Earliest Ypresian (zone E1-2). However, the microfauna from the lower beds of unit $\mathrm{E}$ coming from the Sierra de La Pila sector seems to indicate an earlier input in the distal areas. In $\log 1$, the first level sampled of unit E (sample Pila 21) yields only agglutinated foraminifera without biostratigraphic interest, but the overlying levels (samples P24-P25) contain $P$. pseudobulloides, $P$. inconstans and $P$. uncinata in combination with rare primitive morozovellids (M. praeangulata). This assemblage characterizes zone $\mathrm{P} 2$ of

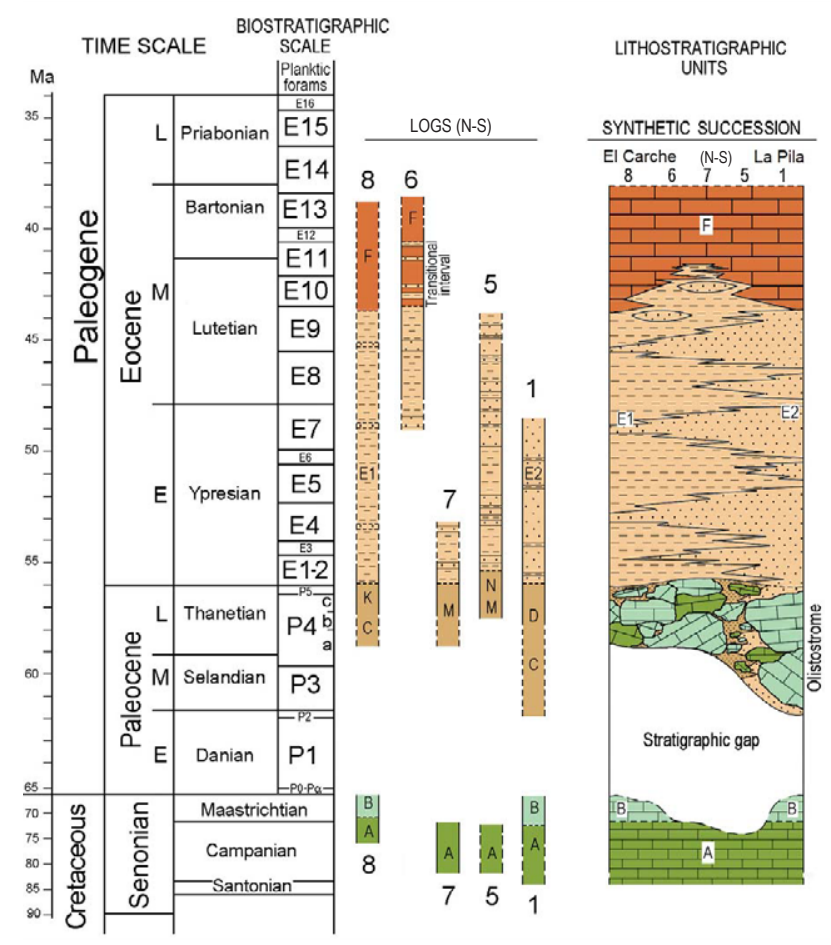

FIGURE 5. Late Cretaceous-Eocene Chronostratigraphy based on the planktonic foraminifera from the study successions in the Sierra de El Carche and Sierra de La Pila sectors. the top of the Early Paleocene. Nevertheless, it is noteworthy that this age is older than datings provided by some samples from the underlying unit $\mathrm{D}$. Although a mélange zone is not clearly visible in this outcrop, it seems probable that the lower part of unit $\mathrm{E}$ in this sector is composed of reworked Paleocene sediments as a result of another olistostromic interval.

Above, the sedimentation throughout unit E seems to be stratigraphically well arranged, showing planktonic foraminifer assemblages (Table 3) indicative of the Late Paleocene-Early Ypresian (samples P29-P30) and the Middle Ypresian (samples P32-P33). The highest observable levels of unit E in the $\log 1$ (sample Pila 22) contain P. inaequispira, $A$. bulbrooki, A. cuneicamerata, $M$. aragonensis, $M$. caucasica and P. micra, pointing to zone E7 of the Middle Ypresian. We have only observed the top of unit $\mathrm{E}$ in the Barranco del Comisario (log 6). In this area, transitional levels (P84) between unit $\mathrm{E}$ and the overl ying Miñano Limestones Fm. of unit F provide A. topilensis, A. bulbrooki, M. crassatus, H. liebusi, G. subconglobata, T. pomeroli, S. corpulenta and S. eocaena, a characteristic assemblage of the zonal interval E10-E11 of the Late Lutetian. The level that marks the top of the transitional interval contains $T$. cerroazulensis in addition to the aforementioned assemblage. This combination limits the biostratigraphic range to the zone E11 covering the Lutetian-Bartonian boundary. Above, the limestones of the Miñano Fm. are traditionally assigned to the Middle-Late Eocene (Hoedemaker, 1973; Rodríguez-Estrella et al., 1980), but do not provide planktonic foraminifera for a more accurate chronology.

Unit $\mathrm{G}$, described as transitional or continental deposits, has not provided planktonic foraminifera. The OligoceneEarly Aquitanian age assigned by Durand Delga and Magné (1958) and later by Ferriz et al. (1993) is compatible with the age of the underlying formations.

The study succession is followed after a main unconformity by units $\mathrm{H}$ and $\mathrm{I}$. The beds containing planktonic foraminifera belong to the basal part of unit I, both in $\log 1$ of the Sierra de La Pila sector (P37-P38) and in the most proximal $\log 2$ (P51-P52). These levels yielded rich assemblages made up mainly of $G$. woodi, G. subquadratus, G. trilobus, G. bisphaericus, P. sicana, $P$. glomerosa, G. praescitula, G. baroemoenensis, $G$. langhiana and $G$. dehiscens, which characterize a Langhian age. The absence of Orbulina ssp. and of G. praemenardii in these assemblages suggests that the unit began to form during the Lower Langhian.

\section{Mineralogy and Petrography}

A total of 28 samples were selected for XRD analysis (using for the analysis a Philips X'Pert MPD Systempert), and 14 samples were analyzed 
TABLE 4. Quantitative mineralogical composition of the bulk samples from Sierra de El Carche and Sierra de La Pila successions. Abbreviations: Cte=calcite; Dol=dolomite; Qtz=quartz; Gy=gypsum; K-Fs=K-feldspar; Plg=plagioclase

\begin{tabular}{|c|c|c|c|c|c|c|c|c|c|c|c|c|c|c|}
\hline \multirow{2}{*}{ Sample } & \multicolumn{4}{|c|}{ Carbonates } & \multicolumn{3}{|c|}{ Phyllosilicates } & \multirow{2}{*}{ Qtz } & \multirow{2}{*}{ Gy } & \multicolumn{3}{|c|}{ Feldspars } & \multirow{2}{*}{$\begin{array}{c}\text { Carbonates } \\
+ \\
\text { Phyllosilicate }\end{array}$} & \multirow{2}{*}{ Unit (Age) } \\
\hline & Cte & Dol & Total & $14 \AA$ & $10 \AA$ & $7 \AA$ & Total & & & $\mathrm{K}-\mathrm{Fs}$ & $\mathrm{Plg}$ & Total & & \\
\hline $\mathrm{C} 3$ & 77 & - & 77 & 9 & 5 & - & 14 & 4 & - & 3 & 2 & 5 & 91 & $A, B$ \\
\hline C5 & 75 & - & 75 & 10 & 5 & - & 15 & 5 & - & 3 & 2 & 5 & 90 & (Senonian- \\
\hline $\mathrm{C} 6$ & 87 & - & 87 & - & 6 & - & 6 & 7 & - & - & - & - & 93 & Maastrichtian) \\
\hline $\mathrm{C} 7$ & 40 & - & 40 & - & 15 & 7 & 22 & 15 & 7 & 10 & 6 & 16 & 66 & \multirow{4}{*}{$\begin{array}{c}\text { C, D, K, M, N (Upper } \\
\text { Paleocene- Lower } \\
\text { Ypresian) }\end{array}$} \\
\hline $\mathrm{C} 8$ & 84 & - & 84 & - & 9 & - & 9 & 7 & - & - & - & - & 93 & \\
\hline $\mathrm{Cg}$ & 70 & - & 70 & 8 & 4 & 4 & 16 & 4 & 2 & 6 & 2 & 8 & 86 & \\
\hline $\mathrm{C} 10$ & 64 & 4 & 68 & 13 & 8 & & 21 & 2 & - & 5 & 4 & 9 & 89 & \\
\hline C11 & 55 & - & 55 & 19 & 5 & 3 & 27 & 7 & 3 & 5 & 3 & 8 & 82 & \multirow{7}{*}{$\begin{array}{c}\text { E } \\
\text { (Lower Ypresian- } \\
\text { Upper Lutetian) }\end{array}$} \\
\hline C12 & 59 & - & 59 & 14 & - & - & 14 & 7 & 5 & 9 & 6 & 15 & 73 & \\
\hline C14 & 70 & - & 70 & 10 & - & - & 10 & 7 & 3 & 4 & 6 & 10 & 80 & \\
\hline C15 & 69 & - & 69 & 8 & 6 & - & 14 & 3 & 4 & 4 & 6 & 10 & 83 & \\
\hline C16 & 12 & 6 & 18 & 24 & 15 & 7 & 46 & 21 & - & 9 & 6 & 15 & 64 & \\
\hline $\mathrm{C} 17$ & 18 & 3 & 21 & 12 & 19 & 6 & 37 & 14 & 5 & 14 & 9 & 23 & 58 & \\
\hline C18 & 10 & 2 & 12 & 10 & 34 & 7 & 51 & 15 & 4 & 11 & 7 & 18 & 63 & \\
\hline $\mathrm{C} 21$ & 15 & 10 & 25 & 8 & 20 & 10 & 38 & 12 & 6 & 10 & 9 & 19 & 63 & $\begin{array}{c}\text { G } \\
\text { (Upper Oligocene- } \\
\text { Lower Aquitanian) }\end{array}$ \\
\hline C23 & 2 & 62 & 64 & - & 14 & - & 14 & 10 & 2 & 5 & 5 & 10 & 78 & \multirow{3}{*}{$\begin{array}{c}\text { I, H, P } \\
\text { (Lower Langhian) }\end{array}$} \\
\hline $\mathrm{C} 24$ & 37 & 7 & 44 & 13 & 14 & - & 27 & 4 & 6 & 9 & 10 & 19 & 71 & \\
\hline $\mathrm{C} 25$ & 55 & 6 & 61 & 10 & 10 & - & 20 & 5 & & 6 & 8 & 14 & 81 & \\
\hline P10 & 75 & - & 75 & 24 & - & - & 24 & 1 & - & - & - & - & 99 & \multirow{6}{*}{$\begin{array}{c}\text { C, D, K, M, N (Upper } \\
\text { Paleocene- Lower } \\
\text { Ypresian) }\end{array}$} \\
\hline P12 & 86 & - & 86 & 13 & - & - & 13 & 1 & - & - & - & - & 99 & \\
\hline P14 & 71 & 4 & 77 & 15 & 7 & - & 22 & 1 & - & - & - & - & 99 & \\
\hline P17 & 77 & - & 77 & 22 & - & - & 22 & 1 & - & - & - & - & 99 & \\
\hline P20 & 61 & - & 61 & 20 & 5 & - & 25 & 9 & - & 5 & - & 5 & 86 & \\
\hline P22 & 71 & - & 71 & 26 & - & - & 26 & 3 & - & - & - & - & 97 & \\
\hline P24 & 21 & 4 & 25 & 7 & 12 & 6 & 25 & 28 & - & 22 & - & 22 & 50 & \multirow{5}{*}{$\begin{array}{c}\text { E } \\
\text { (Lower Ypresian - } \\
\text { Upper Lutetian) }\end{array}$} \\
\hline P27 & 20 & - & 20 & 8 & 15 & 4 & 27 & 35 & - & 18 & - & 18 & 47 & \\
\hline P32 & 21 & - & 21 & 13 & 8 & 8 & 29 & 32 & - & 18 & - & 18 & 50 & \\
\hline P33 & 11 & - & 11 & 12 & 9 & 8 & 29 & 34 & - & 20 & 6 & 26 & 40 & \\
\hline P34 & 15 & 13 & 28 & 12 & 17 & 8 & 37 & 25 & - & 10 & - & 10 & 65 & \\
\hline P38 & 80 & - & 80 & 10 & 6 & & 16 & 4 & - & - & - & - & 96 & $\begin{array}{c}\mathrm{I}, \mathrm{H}, \mathrm{P} \\
\text { (Lower Langhian) }\end{array}$ \\
\hline
\end{tabular}

TABLE 5. Quantitative mineralogy (weight \%) of the clay fraction from Sierra de El Carche (C) and Sierra de La Pila (P) successions. Values of the $(\mathrm{S}+\mathrm{K}) / \mathrm{l}=$ relation according to Daoudi et al. (1995)

\begin{tabular}{cccccc}
\hline \multicolumn{5}{c}{ Sierra de El Carche Sector } \\
\hline Sample Smectite & Illite & Kaolinite & $(\mathrm{S}+\mathrm{K}) / \mathrm{I}$ & Unit (Age) \\
\hline C25 & 56 & 35 & 9 & 1.86 & I, H, P \\
C24 & 60 & 40 & - & 1.50 & (Lower Langhian) \\
C23 & 27 & 61 & 12 & 0.64 & \\
\hline C21 & 20 & 44 & 36 & 1.27 & G (Upper Oligocene \\
& & & & & -Lower Aquitanian) \\
\hline C18 & 42 & 35 & 23 & 1.86 & \\
C17 & 78 & 31 & 21 & 3.19 & \\
C16 & 43 & 39 & 18 & 1.56 & E \\
C15 & 59 & 27 & 14 & 2.70 & (Lower Ypresian \\
C14 & 76 & 24 & - & 3.17 & -Upper Lutetian) \\
C12 & 36 & 52 & 12 & 0.92 & \\
C11 & 67 & 26 & 7 & 2.85 & \\
\hline C10 & 64 & 36 & - & 1.78 & C, D, K, M, N \\
C9 & 79 & 21 & - & 3.76 & (Upper Paleocene \\
C8 & 55 & 35 & 10 & 1.86 & -Lower Ypresian) \\
C7 & 37 & 47 & 16 & 1.13 & A, B \\
\hline C6 & 43 & 27 & 30 & 2.70 & (Senonian- \\
C5 & 43 & 33 & 25 & 2.06 & Maastrichtian) \\
C3 & 50 & 25 & 25 & 3.00 & \\
\hline
\end{tabular}

\begin{tabular}{|c|c|c|c|c|c|}
\hline \multicolumn{6}{|c|}{ Sierra de La Pila Sector } \\
\hline Sample & Smectite & Illite & Kaolinite & $(\mathrm{S}+\mathrm{K}) / \mathrm{I}$ & Unit (Age) \\
\hline P34 & 23 & 44 & 33 & 1.27 & \\
\hline P33 & 11 & 52 & 37 & 0.92 & $E$ \\
\hline P32 & 18 & 44 & 38 & 1.27 & (Lower \\
\hline P27 & 14 & 48 & 38 & 1.08 & $\begin{array}{l}\text { Ypresian } \\
\text {-Upper }\end{array}$ \\
\hline P25 & 17 & 47 & 36 & 1.13 & Lutetian) \\
\hline P24 & 27 & 49 & 24 & 1.04 & \\
\hline P22 & 53 & 36 & 11 & 1.78 & $\mathrm{C}, \mathrm{D}, \mathrm{K}$, \\
\hline P20 & 40 & 37 & - & 1.70 & $\mathrm{M}, \mathrm{N}$ \\
\hline P17 & 75 & - & 25 & - & (Upper \\
\hline P14 & 64 & - & 36 & - & Paleocene \\
\hline P12 & 64 & - & 36 & - & - Lower \\
\hline P10 & 64 & - & 36 & - & Ypresian) \\
\hline
\end{tabular}


petrographically. Quantitative mineralogical analyses were performed on the bulk of samples (Table 4) and on the clay fraction $(<2 \mu \mathrm{m}$; Table 5$)$. For clay-minerals studies, standard procedures (Schultz, 1964; Biscaye, 1965; Alcalá et al., 2001, 2012) were followed. The petrographic analysis indicate both carbonate and siliciclastic petrofacies. Three samples (C22, P26, P31) of the latter (terrigenous arenites) were studied with modal analysis by counting grains with standard procedures (Gazzi, 1966; Dickinson, 1970), while two samples (C19 and P87) were too fine-grained to be studied with a point-count.

The bulk mineralogy of the samples (Table 4) shows high percentages of carbonates, ranging from 87 to $11 \%$, and phillosilicates (51 to 6\%). The Sierra de La Pila succession is generally less carbonated than the Sierra de El Charche. The carbonate is calcite and, from the medium to the upper part of the succession, dolomite. Minor components are quartz, feldspars, and gypsum. Quartz and feldspars increase in percentage upwards in the succession, reaching their maximum in unit E (Lower Ypresian-Upper Lutetian) when the calcite decreases.

The clay mineralogy of both successions is characterized by smectite-illite-kaolinite (Table 5). Table 5 also shows the $(\mathrm{S}+\mathrm{K}) / \mathrm{I}$ ratio to provide information on the relative sea-level variations according to Daoudi et al. (1995).

The petrographic analysis of 14 samples $(\mathrm{C} 1, \mathrm{C} 2$, C4, C13, C19, C20, C22 from Sierra de El Carche; P13, P15, P26, P31, P87, P93, P35 from Sierra de La
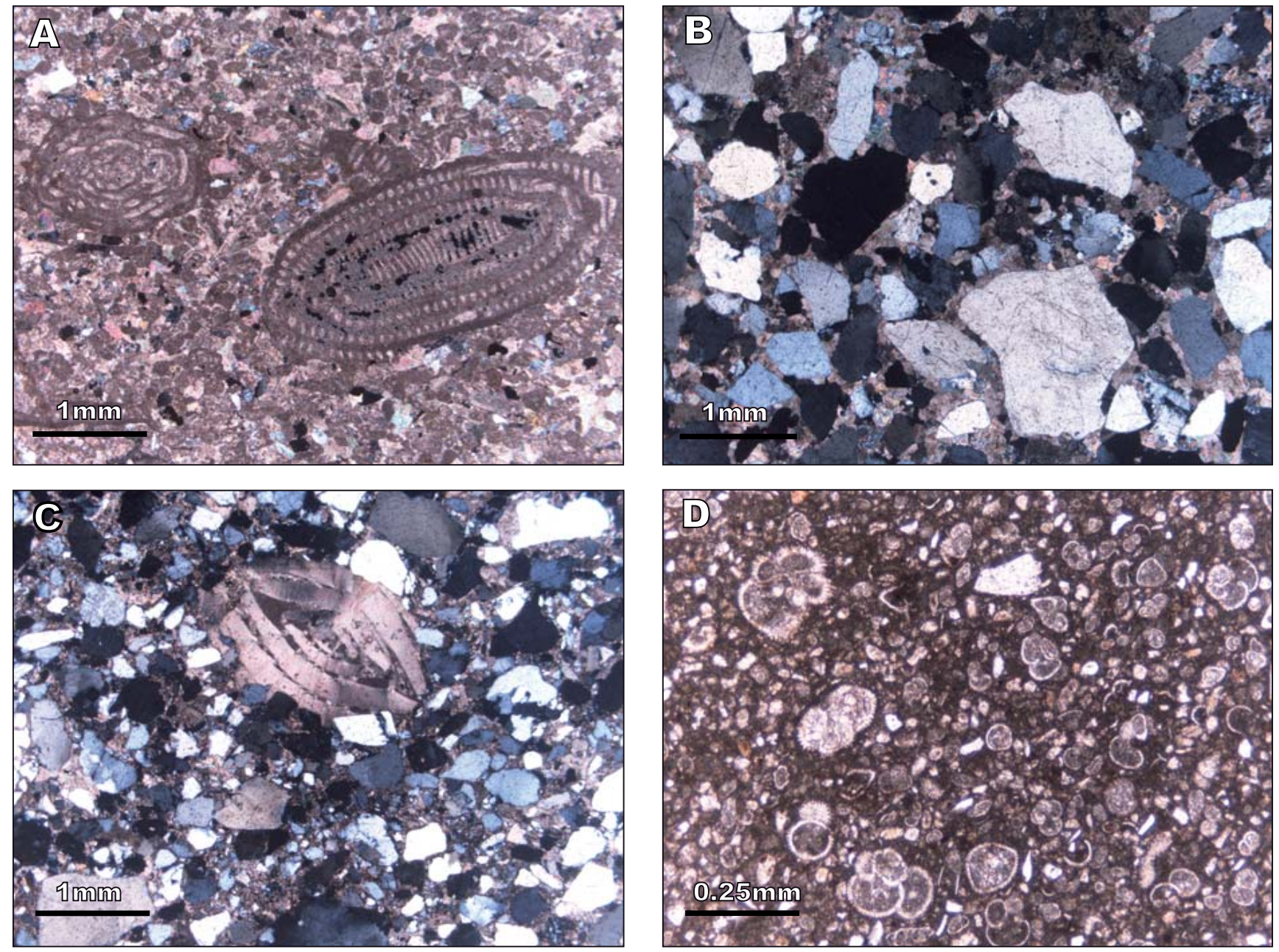

FIGURE 6. Photomicrographs of representative lithofacies of the Sierra de El Carche (A and B) and Sierra de La Pila (C and D) successions. A) Calcarenite with larger foraminifera (Alveolinae), pellets, planktonic and benthic foraminifera (miliolids), and small crystals of quartz (sample C20, cross-polarized light); B) coarse-grained quartz-arenite with dominant monocrystalline quartz, rare mica flakes and feldspars cemented by patches of sparry cement (Sample C22, cross-polarized light); C) quartz-arenite with nummulites, quartz, mica flakes, feldspars and opaque minerals (Sample P31, cross-polarized light); D) wackestone very rich in planktonic foraminifera, with rare crystals of quartz (Sample P93, plane-polarized light). 
Pila) indicate the presence of biomicritic limestones (wackestone, Fig. 6D), packstones/grainstones, calcarenites (Fig. 6A), and quartz-arenites (Fig. 6B, C). Units A, B, C, D, K, M, and N (Senonian to Lower Ypresian) are made up of biomicritic limestones (wackestone). Unit E (Lower Ypresian-Upper Lutetian) is characterized by fine-grained calcarenites and quartz-arenites $\left(\mathrm{Q}_{98} \mathrm{~F}_{2} \mathrm{~L}+\mathrm{C}_{0}, \quad \mathrm{Q}_{95} \mathrm{~F}_{3} \mathrm{~L}+\mathrm{C}_{2}\right)$ composed mainly of mono- and polycrystalline quartz, mica flakes (both muscovite and biotite), feldspars (with plagioclase as the dominant phase) and opaque minerals. Units $\mathrm{F}$ and $\mathrm{J}$ are made up of calcarenites with larger foraminifera (nummulites and alveolines; Fig. 6A, C) and very small rounded and elongated micritic grains (pellets), sparitic fragments, and minor amounts of planktonic and benthic foraminifera (miliolids). Unit G (Upper OligoceneLower Miocene) is characterized by coarse-grained quartz-arenite $\left(\mathrm{Q}_{98} \mathrm{~F}_{2} \mathrm{~L}+\mathrm{C}_{0}\right)$ composed of dominant monocrystalline quartz (rare polycrystalline), subordinate mica (mainly muscovite) and feldspars.

\section{DISCUSSION}

The main characteristics of the stratigraphic record, a modern definition of the chronostratigraphy of the formations, and a better knowledge of the prevailing mineralogical-petrographic rocks found in the study area support the following considerations.

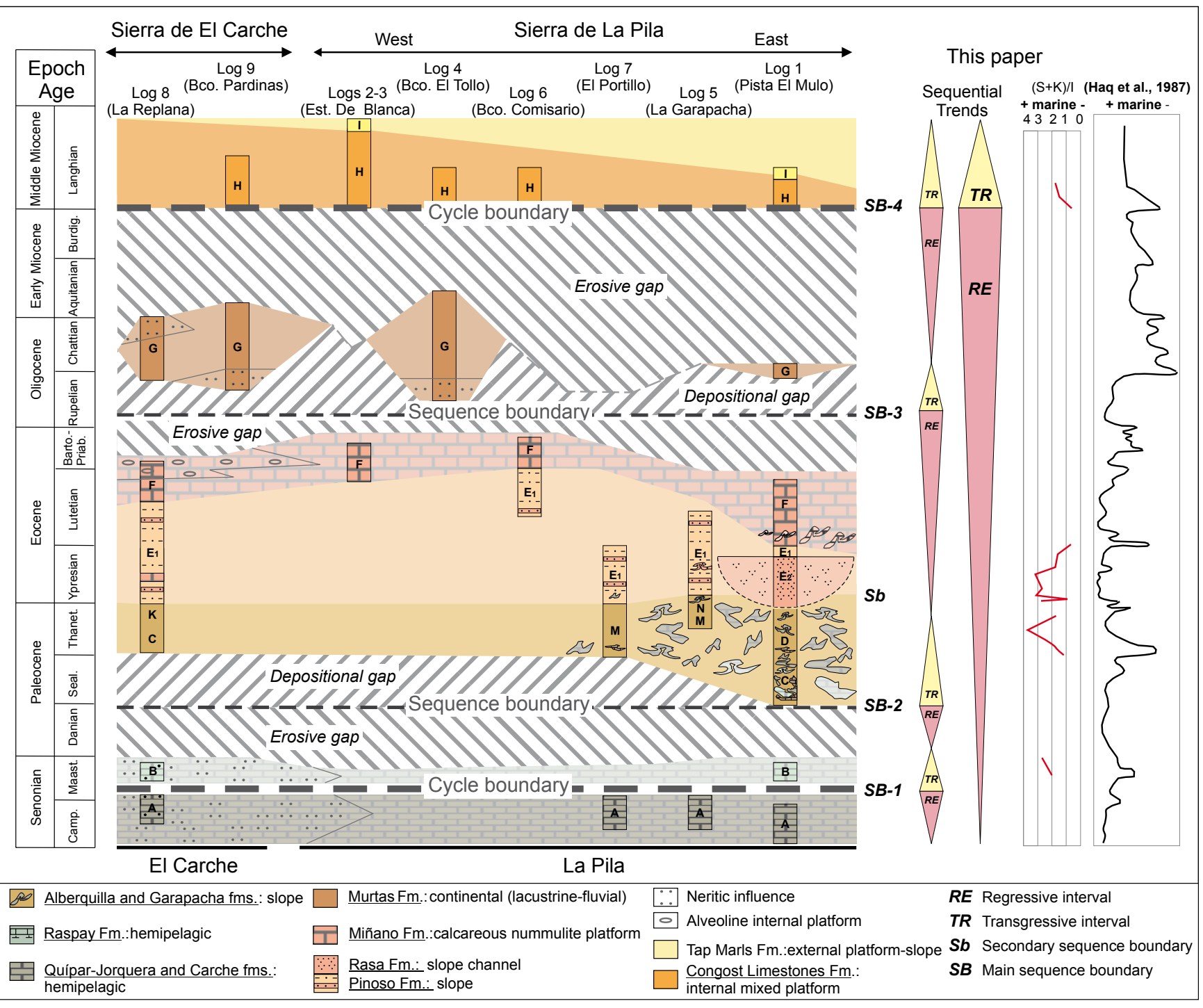

FIGURE 7. Interpretative stratigraphic architecture of the study area, showing depositional sequences and lateral facies variation. The stratigraphic gaps associated to the unconformities are interpreted as depositional or erosive. The depositional trends deduced from the facies evolution are compared with the synthetic marine curve for the whole area drawn with the [(S+K)/l] ratio and with the global eustatic curve from Haq et al. (1987). 


\section{Unconformities, depositional sequences and evolutionary trends}

The sedimentary record shows four main unconformity boundaries (SB-1 to SB-4) identified, in most cases, by the existence of biostratigraphic gaps and erosive surfaces. The stratigraphic discontinuities can be arranged into two sedimentary cycle boundaries (SB-1 and SB-4) and depositional sequence boundaries (SB-2 and SB-3). Thus, the Upper Cretaceous-Lower Miocene sedimentary record can be divided by the following discontinuities (Fig. 7):

SB-1: This intra-Maastrichtian unconformity boundary coincides with an intra-Campanian to intra-Maastrichtian biostratigraphic gap registered in $\log 1$ (Sierra de La Pila) and $\log 8$ (Sierra de El Carche), separating the unit A (Carche and Quípar-Jorquera fms.) from the unit B (Raspay Fm.). This unconformity divides the post Lower LiassicSenonian p.p. sedimentary cycle from the Maastrichtian p.p. to Lower Miocene p.p. sedimentary cycle.

SB-2: This intra-Paleocene unconformity boundary, formed by a major Early-Middle Paleocene biostratigraphic gap, is registered in the logs 1, 5 and 7 (Sierra de La Pila), and $\log 8$ (Sierra de El Carche). This unconformity bounds unit B (Raspay Fm.) from the units $\mathrm{C}$ and $\mathrm{K}$ (Alberquilla Fm.) and C, D, M, and N (Garapacha stratigraphic unit). SB-1 and SB-2 delimit a depositional sequence with a sedimentary record from the Middle-Upper Maastrichtian p.p.

SB-3: This unconformity is considered intra-Oligocene in age even if the vertical extension of the biostratigraphic gap comprises from the latest Eocene-Early Oligocene p.p. checked in logs 1 and 4 (Sierra de La Pila) and logs 8 and 9 (Sierra de El Carche). SB-2 and SB-3 are, respectively, the lower and the upper boundaries of a sedimentary depositional sequence Upper Paleocene to Lutetian/ Bartonian boundary in age. This includes different units (C, D, M, N, K, E and F) and formations (see Table 1). SB-3 upwardly separates unit F (Miñano Limestone Fm.) from unit $\mathrm{G}$ (Murtas Fm.).

SB-4: This last unconformity boundary has been dated as intra-Langhian and it would be related to a compressive or strike-slip pre-paroxysmal deformative phase of the end of the Early Burdigalian (Arias et al., 2004). Thus, after this deformation phase, the sedimentation could have been reestablished during the Early Langhian. This unconformity marks the beginning of the Lower Langhian-Upper Miocene p.p. sedimentary cycle occurring at the base by units $\mathrm{H}$ and $\mathrm{I}$ as reported in Figure 7, but not examined in this paper. These units unconformably overlie unit G (Murtas Fm.), as recognized in $\operatorname{logs} 1,2,4$, and 6 (Sierra de La Pila) and in the $\log 9$ (Sierra de El Carche). SB-3 and SB-4 delimit an Oligocene to Early Aquitanian depositional sequence (unit G), according to Durand-Delga and Magné (1958) and Ferriz et al. (1993).
In addition, a local angular unconformity surface ( $\mathrm{Sb}$ in the Fig. 7), mapped (Fig. 2) and observed in log 1 (Sierra de La Pila; Fig. 4), separates unit D (Garapacha stratigraphic unit) from unit E2 (Rasa Sandstones Mbr). This minor unconformity Early Ypresian in age seems to correspond to an erosive channelized environment which favored the terrigenous supply along the slope of the basin and is not considered a sequence boundary.

In summary, the recognition of unconformity boundaries allows the division of the study succession into five depositional sequences: i) pre-intra-Maastrichtian (Senonian); ii) Middle-Upper Maastrichtian p.p.; iii) Upper Paleocene to Lutetian/Bartonian boundary; iv) Oligocene to Lower Aquitanian and v) Lower Langhian to Upper Miocene p.p.

The intra-Maastrichtian and the Aquitanian p.p.-Earliest Langhian unconformities are considered sedimentary-cycle boundaries. The first is correlated (see below) with the positive inversion of the tectonic regime (from distension to compression), which in general marks the end of the expansion of the Tethyan Ocean. The second is related to the beginning of compressional tectonics when blind thrusts (which probably started in the Paleogene) emerge, determining the final orogenic phase. This last Miocene evolution will be examined in a forthcoming paper (study still in progress).

The entire study succession (Senonian p.p. to Middle Miocene p.p.) evidences a clearly regressive general trend from hemipelagic to continental conditions, followed by a transgression during the beginning of the Middle Miocene (Fig. 7). The two older depositional sequences (Senonian, pre-Lower Maastrichtian; Middle-Upper Maastrichtian p.p.; respectively) evidence a hemipelagic and deep marine sedimentation (marly limestones, Scaglia-like) with a moderate terrigenous supply and neritic influence found only in the Sierra de El Carche sector. In these two sequences, no sedimentary trend is discerned from the evolution of the lithofacies. Nevertheless, the existence of unconformity surfaces suggests regressive phenomena during Campanian and Early Paleocene times, followed by rapid transgressions after the unconformities.

The Upper Paleocene to Lutetian/Bartonian boundary depositional sequence shows, after an initial transgression, a regressive trend deduced from a progressive shallowing upward (Fig. 7). This gradually passes from slope deposits characterized by olistostrome and slump levels (Fig. 8A) observed in many units (C, M, K, D and N) and also in the lower part of unit $\mathrm{E}$ (interpreted as a channelized area; $\log 1$ ) to a characteristic carbonate platform, as demonstrated by the presence of typical limestones with larger foraminifera (alveolines and nummulites) from unit F. 

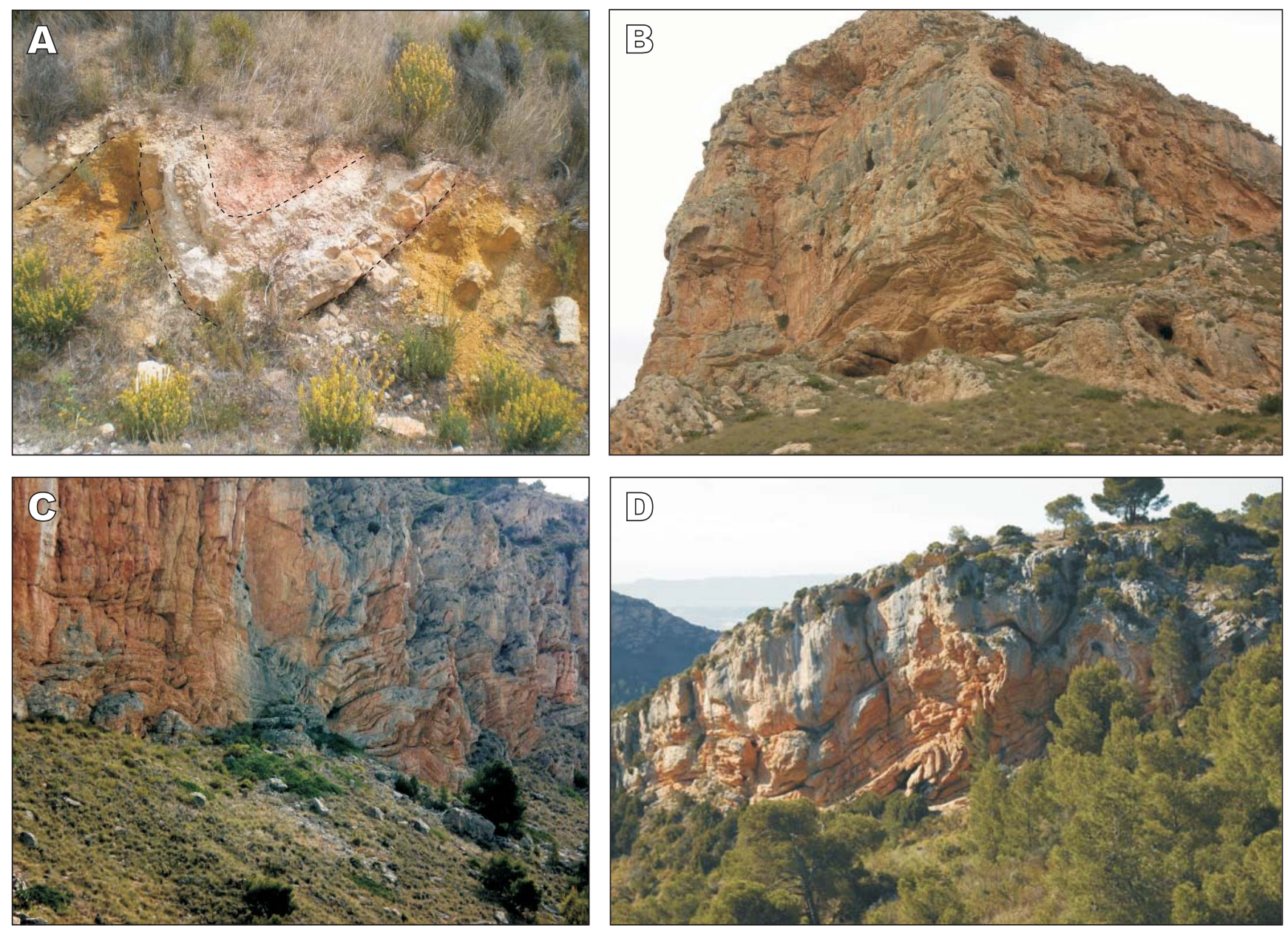

FIGURE 8. Some examples of the syn-sedimentary folds associated with structures interpreted as mega-slumps in the Paleogene succession from the Sierra de La Pila sector (located in Figure 2): A) Late Paleocene of the Barranco del Mulo area; B to D) Middle Eocene from the Sierra de La Pila succession.

The third main unconformity boundary is located at the Early Oligocene being coupled with a gap latest Eocene-Early Oligocene p.p. in age. This unconformity is marked by the presence of a widespread paleokarst structures with pronounced erosive surfaces, indicating an emersion phase at the end of the former depositional sequence (unit F). This period of emersion was followed by a new transgression at the beginning of the Oligocene-Early Aquitanian depositional sequence (unit $\mathrm{G}$ ) indicated by the development of marshy and beach facies. This appears to be followed by a new shallowing upward trending characterized by the lacustrine and fluvial deposits of unit G. The thickness and cartographic distribution of the lithofacies of this unit indicate a more pronounced subsidence in the western Sierra de La Pila (log 4) and Sierra de El Carche (logs 8 and 9) areas and, on the contrary, a relative rising area in the east Sierra de La Pila (logs 1 and 6). This interpretation agrees with the presence of a thick deposition of transitional environment (marshy and beach facies) usually followed by continental lacustrine and fluvial deposits (invariably in the relative subsidence areas) while the rising areas evidence paleokarst surfaces and a thin continental cover.

The fourth sequence boundary should be considered the main unconformity surface separating two depositional cycles and giving way to the Middle Miocene transgressive deposition (units $\mathrm{H}$ and I).

\section{Evidence of Paleogene tectonic activity}

Some evidence of Paleogene deep (blind thrust and folding) tectonic activity in the study area can be deduced from the above observations (Figs. 8; 9):

i) The oldest unconformity separating units A and B can be considered the first sign of a possible tectonic inversion regime (from distension to compression) affecting the western plates (Africa, Mesomediterranean microplate 


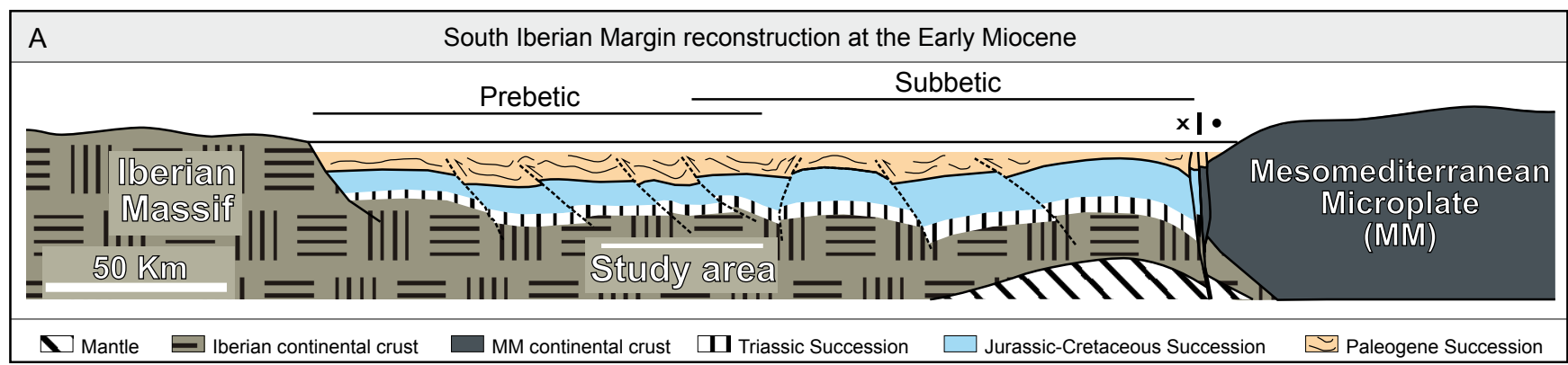

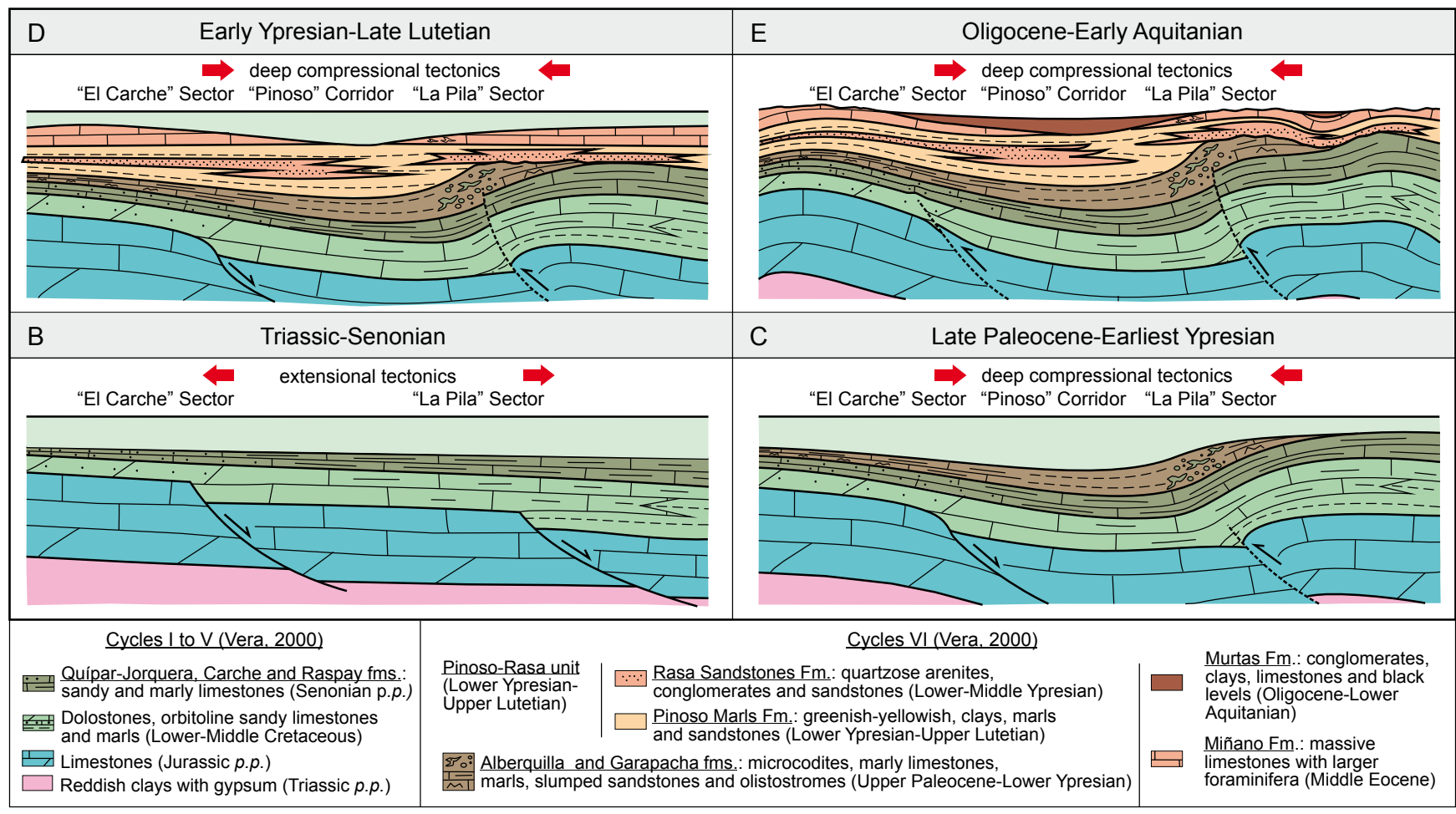

FIGURE 9. A) Early Miocene paleogeographic sketch reconstruction of the whole South Iberian margin with indication of the study area; B to E) paleogeographic evolutionary sketch-models of the Murcia External Betic Zone (Prebetic-Subbetic transition). B) Triassic-Senonian; C) Late Paleocene-Earliest Ypresian; D) Early Ypresian-Late Lutetian; E) Oligocene-Early Aquitanian.

and Iberia) of the Tethyan domain owing to the opening of the Atlantic Ocean and the counter-clockwise rotation of African Plate (Williams et al., 1989). During this period a slight difference in the neritic and Iberian terrigenous influence occurred from north to south (more neritic and terrigenous in Sierra de El Carche sector).

ii) The intra-Paleocene unconformity (biostratigraphic gap affecting the $\mathrm{P} 0$ to $\mathrm{P} 4$ p.p. biostratigraphic zones) linked with an onlap of the units $\mathrm{C}, \mathrm{M}, \mathrm{N}, \mathrm{K}$, and $\mathrm{D}$, from south to north (Fig. 5), indicate some paleogeographic reorganization consisting of the beginning of the environmental and basin paleotopography diversification in clear contrast to the substantial Cretaceous uniformity shown by the monotonous facies (Fig. 9). Moreover, the presence of olistostrome and slump levels (Fig. 8) during the Late Paleocene indicates a slope deposition in the southern part (Sierra de La Pila sector, Fig. 9) suggesting a close rising area (southward and probably the External Subbetic) with a clear tectonic instability of its margin. This rising area is thought to be related to reactivation of former normal faults as blind reverse faults at the latest Cretaceous.

iii) Paleogeographic changes during the EarlyMiddle Eocene are detectable by the: i) variability of the thicknesses of the facies, ii) existence of local unconformity (channelized sandstones in unit E2), iii) occurrence of slumps in the unit E1. These characters may be also point to a moderate tectonic folding progression (probably owing to blind thrusts) during the Early-Middle Eocene (Fig. 9).

iv) There is a noteworthy basal level of unit F (Fig. 4) cropping out in the Barranco del Mulo (Fig. 8B, C) and Collado de las Yeguas (Fig. 8D). This consists of a marker- 
slump-bed registered in the Middle Eocene carbonate platform. This level evidences the tendency toward the installation of an external platform (unit F) affected by tectonic instability and producing variability in thickness at its base (Figs. 5; 7; 9). This nummulitic platform is more developed in the shallow areas (Sierra de El Carche and southern Sierra de La Pila) and less in the deep ones (west Sierra de La Pila and probably the Pinoso Corridor) where the unit E is younger. In the Sierra de El Carche sector among the nummulites, alveolines also appear, indicating a more internal platform in comparison with the Sierra de La Pila sector.

v) The distribution of the unit $\mathrm{G}$ from the OligoceneLower Aquitanian appears today in synclines or on the flanks of the large anticlinal structures of the Sierra de La Pila and Sierra de El Carche areas. Unit G is unconformably sealed by the Middle Miocene deposits in some areas. This unit shows variability in facies (from marshy to clear continental: fluvial and lacustrine) and thicknesses. Both features appear to indicate a folding prior to the deposition of unit G. This folding allowed subsidence areas where the Oligocene to Lower Aquitanian depositions were preferably sedimented and later preserved during Middle Miocene erosion.

\section{Paleoenvironmental and paleoclimatic evolution}

The minero-petrographic analyses provided information on paleoenvironmental and paleoclimatic evolution. Moreover, the application of the $[(\mathrm{S}+\mathrm{K}) / \mathrm{I}]$ ratio (Daoudi et al., 1995) is indicative of the relative sea-level changes (Fig. 4), especially when correlated with the global eustatic curve (Fig. 7) from Haq et al. (1987).

The Late Cretaceous succession shows a high content in calcite and a low percentage of quartz related to the deposition on a carbonate platform. The presence of siliciclastic material (though a low percentage) may indicate deposition in the relative proximity of the seashore more evident in the Sierra de El Carche. Since the $[(\mathrm{S}+\mathrm{K}) / \mathrm{I}]$ ratio indicates a relative sea-level rise in concordance with the global eustatic curve (Fig. 7), a tectonic influence could explain the terrigenous input.

During the Late Paleocene-Early Ypresian, the amount of calcite and smectite significantly increased while quartz, feldspar, and kaolinite decreased, signaling the beginning of a relative sea-level rise with more pelagic conditions in the Sierra de La Pila sector. The $[(\mathrm{S}+\mathrm{K}) / \mathrm{I}]$ ratio showed a relative sea-level rise followed at the end by a fall, in accordance with the global curve.

In the Early Ypresian-Late Lutetian the $[(\mathrm{S}+\mathrm{K}) / \mathrm{I}]$ ratio indicates several relative sea-level changes consistent with the global curve (Fig. 7). Nevertheless, the compositional data indicates a transition from fine-grained lithotypes into medium- to coarse-grained rocks evidencing a transition to a basinal environment with an event of terrigenous input of erosive material from rising areas (possible anticlines). At the same time, a climatic wetting is indicated by the increase in quartz, illite, and kaolinite as well as the decrease in calcite and smectite. The relatively greater abundance of smectite in the Sierra de La Pila succession is probably linked to a more distal environment than the Sierra de El Carche sector.

In the Middle-Late Eocene a relative sea-level fall took place as the coarse-grained (calcarenite and packstonegrainstone) petrofacies suggest. Furthermore, the biological associations provide information regarding the features of the depositional environment and paleoclimate. The presence of red algae (Amphiroa) in the Sierra de La Pila succession denotes an internal platform/platform margin with shallow and warm water. The presence of larger foraminifera (nummulites and alveolines), miliolids, and fecal pellets indicate an internal shallow platform with warm waters.

During the Late Oligocene-Early Miocene the presence of dolomite can be considered to have been inherited from the erosion of soils under subtropical climatic conditions (Adatte and Bolle, 2001; Alcalá et al., 2001) confirming a relative sea-level fall and indicating greater proximity for the deposits of the Sierra de El Carche sector. This is also confirmed by the higher content of illite in this succession since illite is considered detrital, suggesting the proximity to a source area subjected to physical erosion (Chamley, 1989).

In the Langhian, a new increase in calcite and smectite as well as the sharp decrease in all the detritic minerals are indicative of a new episode of relative sea-level rise. This is also confirmed by the $[(\mathrm{S}+\mathrm{K}) / \mathrm{I}]$ ratio, and is also consistent with the global curve (Fig. 7).

\section{Correlations and geodynamic implications}

Correlations with other synthetic successions belonging to the External Betic Zone and the Tunisian Tell were made to place the new data in a regional framework and, more generally, in the context of the western Tethyan domain (Fig. 10B). In fact, in addition to the northern Murcia successions (Sierra de La Pila and Sierra de El Carche analyzed here), the following sectors are taken into account: i) North Alicante successions (Guerrera et al., 2006); ii) High Chain and Tajo Almarado, both Internal Subbetic from the Malaga province, previously studied by Alcalá et al. (1998, 2001, 2012, and references therein). In addition, some correlations are also possible 


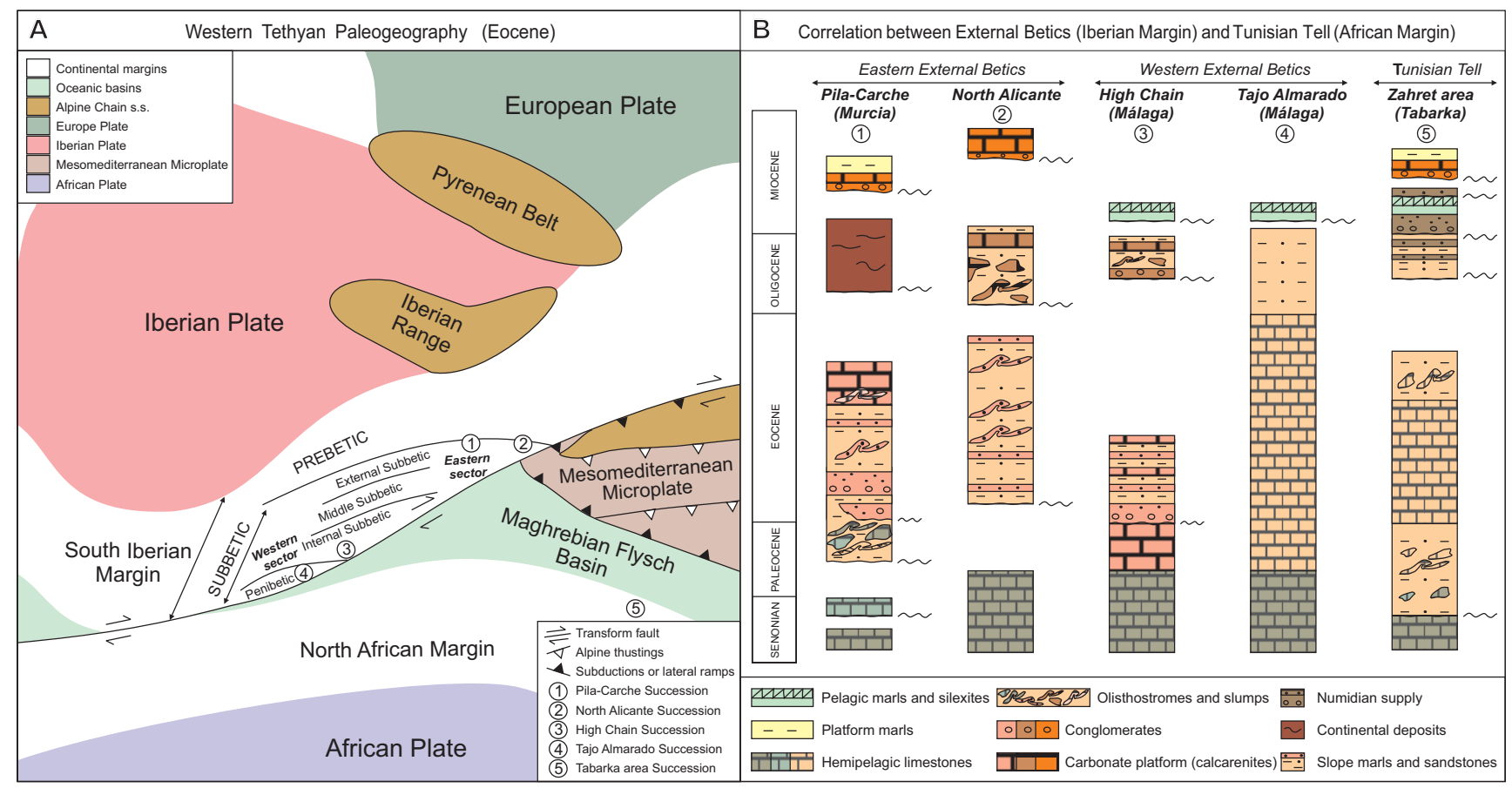

FIGURE 10. A) Paleogeographic-geodynamic framework of the eastern External Betic Zone considered in its regional context of the westernmost Tethyan area; B) Five correlated synthetic stratigraphic successions ( 1 and 2 from eastern External Betic Zone; 3 and 4 from western External Betic Zone): (1) Pila-Carche (Murcia) sector, (2) North Alicante sectors, (3) High Chain (Málaga) sector, (4) Tajo Almarado (Málaga) sector and (5) Zahret area (Tabarka) of the Tunisian Tell (External Zone).

with successions belonging to the external Tunisian Tell (Tabarka area) especially concerning the early Paleogene tectonic activity indicators (Belayouni et al., 2012).

First, it is important to note that the External Betic Zone shows fewer subdomains in the eastern area than in the western one (see Fig. 1). A progressive reduction of the sedimentation areas corresponding to the subdomains of the Subbetic towards the Meseta is clearly visible in the field, to the almost total disappearance of the Subbetic domain in the Alicante region. The cause of these reductions in the subdomains may also be linked with incipient Paleogene tectonics evidenced by some changes in the paleogeographic evolution. This idea is illustrated in Figure 10A, which represents the western Tethyan geodynamic-paleogeographic framework at the Eocene modified from Alcalá et al. (2013; Fig. 7). In Figure 10 the Iberian and African plates with their margins are separated by two other domains the Maghrebian Flysch Basin (MFB, toward the African margin) and the Mesomediterranean microplate (future Internal Betic-Rifian Zones), which constitutes the northern margin of the MFB.

The correlated successions (Fig. 10B) show more Paleogene unconformities in the eastern sectors of the External Betic Zone than in the western one, where practically no major unconformities are recognized after the Late Oligocene (High Chain succession) or the Early Burdigalian (Tajo
Almarado succession). Moreover, olistostromic and slumped deposition is clearly present in the eastern successions at several stratigraphic levels (Upper Paleocene, Eocene and Oligocene), while in the western area, similar features are found only in the High Chain succession and Late Oligocene.

This tectonic evidence is interpreted here as being due to an east to west asynchronism under the influence of the Mesomediterranean microplate moving westward and pushing the internalmost External Betic Zone. This idea has been partially supported by Alcalá et al. (2012) for the evolution in the western internalmost External Betic Zone (Malaga area) where differences between the High Chain and Tajo Almarado successions (among others) appear. In fact, the differentiations of these successions are probably related to the progressive westward Internal Betic Zone movement. The deformation registered in the eastern External Betics is contemporaneous with the Iberian Range and Pyrenean deformation, suggesting a connected deformative context for the western Tethyan domain. Moreover, the eastern Prebetic seems to undergo a transition northwards to the Iberian Range, as Figure 10 indicates.

Similar evidence of Paleogene tectonics has recently been proposed for the External Tunisian Tell by Belayouni et al. (2012), which are correlated with the events described in this paper. In a detailed study of several successions in the 
area of Tabarka, Belayouni et al. (2012) recognized a cycle boundary at the Cretaceous-Paleocene and several sequence boundaries with associated stratigraphic gaps during the Early Oligocene, Early Aquitanian, and Late Burdigalian. Moreover, during the Paleocene-Eocene, lateral changes of facies from a limestone platform (marked by growing folds) to more distal hemipelagic deposits (pelites) containing evident slump levels. For Belayouni et al. (2012) a tectonic event took place in the Pyrenean age (Paleogene).

Also, with geodynamic-paleogeographic models differing from the one used here, similar Paleogene ages of deformation have been proposed for the Atlas (Frizon de Lamotte et al., 2000) related to the closing of the Maghrebian Tethyan branch, as well as for the Betics (Vergés and Fernàndez, 2012) related to the closing of the
Ligurian Tethyan branch. In our interpretation of the data, these tectonic events are probably due to the activation of the main transform fault (Fig. 10) when the Atlantic Ocean opened. This opening caused a counter-clockwise rotation of the Africa Plate, leading to the closing of the Nevado-Filabrides-Ligure-Piemontese oceanic space (Alpine phase of the middle-late Cretaceous) and, during the Maastrichtian, the inversion (from distension to compression) of the general tectonic regime in the MFB area. During the Paleogene, while the space of the MFB was progressively reduced, the tectonic structures were limited to the basement, creating only incipient, deep and blind structures. At the same time, the system was reactivated by the neo-Alpine phase, caused by the dextral transform fault movement, causing the westward migration of the MM, and the beginning of the deep compressive deformation in the

TABLE 6. Main tectonic sedimentary events reconstructed in the Sierra de El Carche and Sierra de La Pila sectors

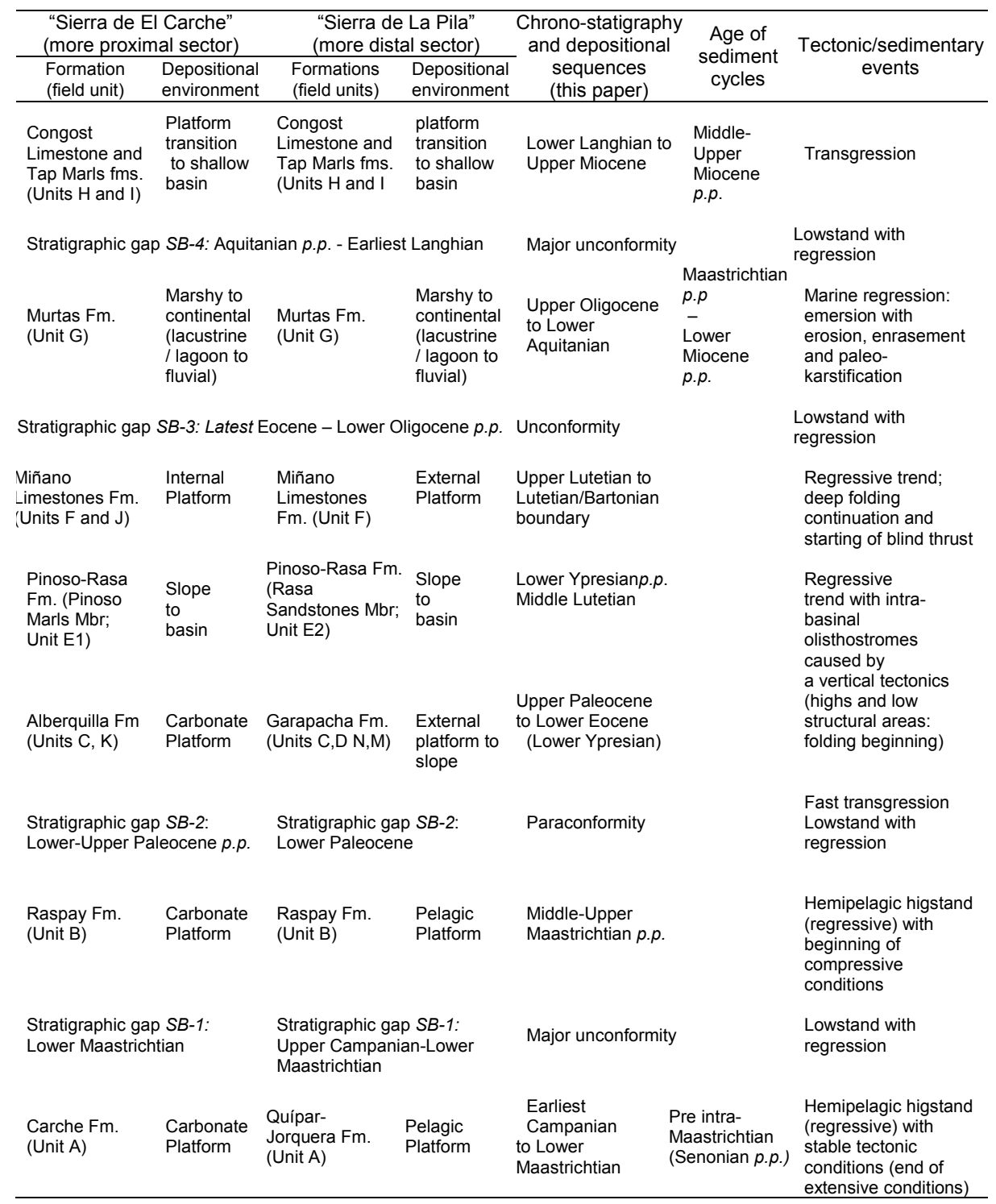


eastermost South Iberian margin (Pila-Carche and Alicante sectors). This last tectonic phase was contemporary with the birth of Pyrenees and Iberian Range.

\section{CONCLUSIONS}

The data collected in this interdisciplinary study support the following conclusions (Table 6):

A regressive trend of the Paleogene sedimentation is registered and the stratigraphic record has been divided into three depositional sequences: i) Middle-Upper Maastrichtian, ii) Upper Paleocene-Middle Eocene and iii) Oligocene-Lower Aquitanian. Some minor transgressiveregressive cycles have also been found.

The depositional sequences and the relative evolutionary trends recognized show a substantial correspondence with the cycles of Vera (2000). Three main sedimentary cycles (Pre-intra-Maastrichtian, Maastrichtian p.p.-Lower Miocene p.p, Middle-Upper Miocene p.p.); and five depositional sequences (1-earliest Campanian to Lower Maastrichtian, 2-Middle-Upper Maastrichtian p.p., 3-Upper Paleocene to Lutetian/Bartonian boundary, 4-Upper Oligocene to Lower Aquitanian, 5-Lower Langhian to Upper Miocene p.p.) have also been recorded.

The Middle Maastrichtian unconformity seems to be related to the inversion of the tectonic regime from distension to compression of the margin/basin system. The Paleogene stratigraphic record shows the effect of tectonic instability recorded during the sedimentation. This is interpreted as being due to compressive deformation in depth, at the basement level, generating blind thrusts and folding structures (Fig. 9).

The main environmental variations are: i) the MiddleLate Maastrichtian period is marked by a terrigenous input during a relative sea-level rise in accord with the global eustatic curve. ii) The Late Paleocene-Early Ypresian period shows a significant increase in calcite and smectite with a decrease in quartz, feldspar, and kaolinite during a relative sea-level rise followed at the end by a fall, in accord with the global curve. iii) In the Early YpresianLate Lutetian $[(\mathrm{S}+\mathrm{K}) / \mathrm{I}]$, several relative sea-level changes took place also in accord with the global curve, while the compositional data indicates terrigenous input, a climatic wetting and tectonic rising areas near of the Sierra de La Pila sector (formerly the distal area). iv) During the MiddleLate Eocene and the Oligocene shallowing and a climatic warming reaching subtropical conditions occurred, while during the Langhian a relative sea-level rise began.

The environmental evolution starts from hemipelagic and homogeneous conditions for the Late Cretaceous interval, a diversification in realms varying from platform to slope and basin during the Paleocene together with a significant tectonic activity reflected by the presence of olistostromes and slumps. This tectonic activity appears to continue during the Eocene, Oligocene, and Early Miocene, as indicated by the increased terrigenous supply and the shallowing upward trend, giving marine-platform conditions at the Middle-Late Eocene and continental deposits at the Late Oligocene-Early Aquitanian.

The proposed evolution concerning the External Zone of the Betic Cordillera was also found in the Paleogene of the Tunisian Tell where an early and deep tectonic deformation occurs. Moreover, during the Paleogene, the External Betic domain represented the paleogeographic transition between the Iberian Range and the Internal Betic Zone and the two domains were very close. This paleogeography represents a crucial area to understand the marginal (lateral) evolution of the chain, also given that a cylindrical perspective is not possible. Thus, a paleogene deformation (Iberian or Pyrenean-like) could affect the sedimentation of the eastern South Iberian margin related to the general western Tethyan geodynamic framework. This young (early) tectonic activity appears not to affect other western sectors of the External Betic Zone, supporting the proposal of an asynchronism in the deformation related to the western migration of the Mesomediterranean microplate (the future Internal Betic-Rifian Zone). In all successions belonging to the Maghrebian Flysch Basin, this (early) tectonic activity was not previously detected.

\section{ACKNOWLEDGMENTS}

Research was supported by Urbino University found (responsible F. Guerrera), CGL2009-09249, CGL2011-30153CO2-02 and CGL2012-32169 research projects (Spanish Ministry of Education and Science) and by Research Groups and projects of the Generalitat Valenciana from Alicante University (CTMA-IGA), and Junta de Andalucía (RNM-146). The English of the manuscript was revised by Mr. David Nesbitt.

\section{REFERENCES}

Adatte, T., Bolle, M.P., 2001. Paleocene-early Eocene climatic evolution in the Tethyan realm: clay mineral evidence. Clay Minerals, 36, 249-261.

Alcalá, F.J., López-Galindo, A., Serra-Kiel, J., Martín-Martín, M., 1998. Mineralogía del Terciario de la Alta Cadena (NE de la provincia de Málaga). Implicaciones paleogeográficas y sedimentológicas. Boletín de la Sociedad Española de Mineralogía, 21, 163-175.

Alcalá, F.J., Martín-Martín, M., López-Galindo, A., 2001. Clay mineralogy of the Tertiary sediments in the Internal 
Subbetic of Málaga Province, S Spain: implications for geodynamic evolution. Clay Minerals, 36, 615-620.

Alcalá, F.J., López-Galindo, A., Martín-Martín, M., 2012. Clay mineralogy as a tool for sequence-stratigraphy division and detailed paleogeographic reconstructions: an example from Upper Oligocene-early Aquitanian Western Internal South Iberian Margin. Geological Journal, 48, 363-375. DOI: $10.1002 / \mathrm{gj} .2451$

Alcalá, F.J., Guerrera, F., Martín-Martín, M., Raffaelli, G., Serrano, F., 2013. Geodynamic implications derived from Numidian-like distal turbidites deposited along the Internal-External Domain Boundary of the Betic Cordillera (S Spain). Terra Nova, 25, 119-129. DOI: 10.1111/ter.12014

Alfaro-García, P., 1995. Neotectónica en la Cuenca del Bajo Segura (Extremo oriental de la Cordillera Bética). Doctoral Thesis. Alicante, Universidad de Alicante, 219pp.

Arias, C., Castro, J.M., Chacón, B., Company, M., Crespo-Blanc, A., Diaz de Federico, A., Estévez, A., Fernández, J., GarcíaHernández, M., López-Garrido, A.C., Martín-Algarra, A., Martín-Chirivet, J., Molina, J.M., Morata, D., Nieto, L.M., O’Dogherty, L., Pérez-López, A., Puga, E., Rey, J., Rivas, P., Ruiz-Ortiz, P.A., Sandoval, J. Sanz de Galeano, C. Vera, J.A., Vilas L., 2004. Zonas Externas Béticas. In: Vera, J.A. (ed.). Geología de España. Sociedad Geológica de España, Instituto Geològico y Minero de España (IGME), 884pp.

Azéma, J., 1966a. Sur l'existence d'une zone intermédiaire entre Prébétique et Subbétique dans les provinces d'Alicante et de Murcie (Espagne). Paris, Comptes Rendus de l'Académiedes Sciences, 260, 4020-4023.

Azéma, J., 1966b. Géologie des confins des provinces d'Alicante et de Murcia (Espagne). Bulletin Societé Géologique de France, 8(7), 80-86.

Azéma, J., 1977. Étude géologique des Zones Externes des Cordillères Bétiques aux confins des provinces d'Alicante et de Murcia (Espagne). Doctoral Thesis. París, Université Pierre et Marie Curie, 396pp.

Belayouni, H., Guerrera, F., Martín-Martín, M., Serrano, F., 2012. Stratigraphic update of the Cenozoic Sub-Numidian formations of the Tunisian Tell (North Africa): Tectonic/ sedimentary evolution and correlations along the Maghrebian Chain. Journal of African Earth Sciences, 64, 48-64.

Biscaye, P.E., 1965. Mineralogy and Sedimentation of Recent Deep Sea Clay in the Atlantic Ocean and Adjacent Seas and Oceans. Geological Society of America. Bulletin, 76, 803-832.

Chacón, B., Martín-Chivelet, J., 2005. Subdivisión litoestratigráfica de las series hemipelágicas de edad Coniaciense-Thanetiense en el Prebético oriental (SE, España). Revista de la Sociedad Geológica de España, 18(1-2), 3-20.

Chacón, B., Martín-Chivelet, J., Gräfe, K.-U., 2004. Latest Santonian to latest Maastrichtian planktic foraminifera and biostratigraphy of the hemipelagic successions of the Prebetic Zone (Murcia and Alicante provinces, south-east Spain). Cretaceous Research, 25, 585-601.
Chamley, H., 1989. Clay sedimentology. New York, SpringerVerlag, 623pp.

Daoudi, L., Deconinck, J.F., Witan, O., Rey, J., 1995. Impact des variation du niveau marin sur les argiles: exemple du Crétacé inférieur du bassin d'Essaouira (Maroc). Paris, Comptes Rendus de l'Académiedes Sciences, Série II a, 320, 707-711.

De Smet, M.E.M., 1984a. Investigations of the Crevillente Fault Zone and its Role in the Tectogenesis of the Betic Cordilleras, Southern Spain. Amsterdam, Free University Press, 174pp.

De Smet, M.E.M., 1984b. Wrenching in the external zone of the Betic Cordilleras, southern Spain. Tectonophysics, 107, 5779.

Dickinson, W.R., 1970. Interpreting detrital modes of greywacke and arkose. Journal Sedimentary Petrology, 40, 695-707.

Durand-Delga, M., Magné, J., 1958. Données stratigraphiques et micropaléontologiques sur le nummilitique de l'Est des Cordillères Bétiques (Espagne). Revue de Micropaléontologie, 1-3, 155-175.

Ferriz, J., Freudenthal, M., Martín-Suarez, E., 1993. The oldest mammals from the Betic Cordillera: The Oligocene of the Internal Prebetic (Nerpio, Albacete, SE Spain). Geobios, 26(5), 625-631.

Foucault, A., 1960. Découverte d'une nouvelle unité tectonique sous le massif subbetique de la Sierra Sagra (Andalousie). Paris, Comptes Rendus de l'Académiedes Sciences, 250, 20-38.

Frizon de Lamotte, D., Saint Bezar, B., Bracène, R., Mercier, E., 2000. The two main steps of the Atlas building and geodynamics of the western Mediterranean. Tectonics, 19, 740-761.

Gazzi, P., 1966. Le arenarie del flysch sopracretaceo dell'Appennino Modenese; correlazioni con il Flysh di Monghidoro. Mineralogia Petrografia Acta, 12, 69-97.

Griffin, J.J., Windom, H., Goldberg, E.D., 1968. The distribution of clay minerals in the world oceans. Deep-Sea Research, 15, 433-459.

Guerrera, F., Martín-Algarra, A., Perrone, V., 1993. Late Oligocene-Miocene syn-late-orogenic successions in Western and Central Mediterranean Chains from the Betic Cordillera to the Southern Apennines. Terra Nova, 5, 525544.

Guerrera, F., Martín-Martín, M., Perrone, V., Tramontana M., 2005. Tectono-sedimentary evolution of the southern branch of the Western Tethys (Maghrebian Flysch Basin and Lucanian Ocean). Terra Nova, 17, 358-367.

Guerrera, F., Estévez,A., López-Arcos, M., Martín-Martín, M., MartínPérez, J.A., Serrano, F., 2006. Paleogene tectono-sedimentary evolution of the Alicante Trough (External Betic Zone, SE Spain) and its bearing on the timing of the deformation of the South-Iberian Margin. Geodinamica Acta, 19(2), 87-101.

Guerrera, F., Martín-Algarra, A., Martín-Martín, M., 2011. Tectono-sedimentary evolution of the Numidian Formation and Lateral Facies (southern branch of the western 
Tethys): constraints for central-western Mediterranean geodynamics. Terra Nova, 24, 34-41.

Haq, B.U., Hardebol, J., Vail, P.R., 1987. Chronology of fluctuating sea levels since the Triassic. Science, 235, 1156-1167.

Hoedemaeker, P.J., 1973. Olistostromes and other delapsional deposits, and their occurrence in the region of Moratalla (Prov. of Murcia, Spain). Scripta Geologica, 19, 1-207.

Luterbacher, H.P., Ali, J.R., Brinkhuis, H., Gradstein, F.M., Hooker, J.J., Monechi, S., Ogg, J.G., Powell, J., Röhl, U., Sanfilippo, A., Schmitz, B., 2004. The Paleogene period. In: Gradstein, F., Ogg, J.G., Smith, A. (eds.). A Geologic Time Scale 2004. Cambridge, Cambridge University Press, 384-408.

Martín-Algarra, A., 1987. Evolución geológica Alpina del contacto entre Zonas Internas y las Zonas Externas de la Cordillera Bética. Doctoral Thesis. Granada, Universidad de Granada, 1171pp.

Martínez del Olmo, W., Leret Verdú, G., Suárez Alba, J., 1986. La estructuración diapirica del Sector Prebético. Geogaceta, 1, 43-44.

Montenat, C., 1977. Les bassins néogènes et quaternaires du Levant d'Alicante à Murcia (Cordillères Bétiques orientales, Espagne). Stratigraphie, paléontologie et évolution dynamique. Documents du Laboratoire de Géologie de la Faculté des Sciences de l'Université de Lyon, 69, 345pp.

Nicklés, R., 1896a. Sur les terrains secondaires des provinces de Murcia, Almerie, Grenade et Alicante (Espagne), (In French). Paris, Comptes Rendus de l'Académie des Sciences, 122, 550-553.

Nicklés, R., 1896b . Nota acerca de los terrenos secundarios de las provincias de Murcia, Almería, Granada y Alicante (In Spanish). Boletin de Comunicaciones del Mapa Geológico de España, 23, 145-149.

Olsson, R.K., Hemleben, C., Berggren, W.A., Huber, B.T., 1999. Atlas of Paleocene Planktonic Foraminifera. Smithsonian Contribution Paleobiology, 85, 252pp.

Pearson, P.N., Olsson, R.K., Huber, B.T., Hemleben, C., Berggren, W.A. (eds.), 2006. Atlas of Eocene Planktonic Foraminifera. Cushman Foundation, 41 (Special Publications), 513pp.
Rodríguez-Estrella, T., 1977. Síntesis geológica del Prebético de la provincia de Alicante. I y II. Boletín Geológico y Minero de España, Instituto Geológico y Minero de España (IGME), LXXXVIII-III, 183-214.

Rodríguez-Estrella, T., 1979. Geología e hidrogeología del sector de Alcaraz-Liétor-Yeste (provincia de Albacete). Síntesis geológica de la Zona Prebética. Doctoral Thesis. 97. Colecciones y Memorias del Instituto Geológico y Minero de España (IGME), 278, 290pp.

Rodríguez-Estrella, T., Granados y Granados, L.F., SaavedraGarcía, J.L., González-Asensio, A., 1980. Estudio geológico en el sector de Carche-Salinas. Zona Prebética (Provincias de Murcia y Alicante). Boletín Geológico y Minero de España, Instituto Geológico y Minero de España (IGME), XCI-IV, 527-548.

Sanz de Galdeano, C., 1983. Los accidentes y fracturas principales de las Cordilleras Béticas. Estudios Geológicos, 39, 157-167.

Schultz, L.G., 1964. Quantitative interpretation of mineralogical composition from X-ray and chemical data for the Pierre Shale. U.S. Geological Survey, 391-C (Professional Paper), 31pp.

Seyfried, H., 1978. Der subbetische Jura von Murcia (SüdostSpanien). Geologisches Jahrbuch, 29, 3-201.

Vera, J.A., 2000. El Terciario de la Cordillera Bética: estado actual de conocimientos. Revista de la Sociedad Geológica de España, 12(2), 345-373.

Vergés, J., Fernàndez, M., 2012. Tethys-Atlantic interaction along the Iberia-Africa plate boundary: The Betic-Rif orogenic system. Tectonophysics, 579, 144-172.

Williams, G.D., Powell, C.M., Cooper, M.A., 1989. Geometry and kinematics of inversion tectonics. In: Cooper, M.A., Williams, G.D. (eds.). Inversion Tectonics. Geological Society of London, 44 (Special Publications), 3-15.

Windom, H.L., 1976. Lithogenous material in marine sediments. In: Riley, J.P., Chester, R. (eds.). Chemical Oceanography. London, Academic Press, 103-135.

Manuscript received April 2013;

revision accepted May 2014;

published Online June 2014. 